\title{
Defining the Concepts of a Smart Nursing Home and Its Potential Technology Utilities That Integrate Medical Services and Are Acceptable to Stakeholders: a Scoping Review
}

\author{
Yuanyuan Zhao \\ Universiti Putra Malaysia \\ Fakhrul Zaman Rokhani \\ Universiti Putra Malaysia \\ Shariff-Ghazali Sazlina \\ Universiti Putra Malaysia \\ Navin Kumar Devaraj \\ Universiti Putra Malaysia \\ Jing Su \\ Hainan Medical University \\ Boon-How Chew ( $\square$ chewboonhow@upm.edu.my)
}

Universiti Putra Malaysia

\section{Research Article}

Keywords: Smart technology, nursing homes, integration of medical services, healthcare, quality of care, stakeholders' acceptability

Posted Date: December 10th, 2021

DOI: https://doi.org/10.21203/rs.3.rs-1089886/v1

License: (c) (i) This work is licensed under a Creative Commons Attribution 4.0 International License. Read Full License

Version of Record: A version of this preprint was published at BMJ Open on February 1st, 2021. See the published version at https://doi.org/10.1136/bmjopen-2020-041452. 


\section{Abstract}

\section{Background and objectives:}

Smart technology in nursing home settings has potential to elevate an operation that manages a larger number of elderly residents. However, the concepts, definitions and scopes of 'smartness', integrated medical services and stakeholders' acceptability of a smart nursing home are less clear This scoping review aims to define a smart nursing home and examine the qualitative evidence on technological feasibility, integration of medical services and acceptability of the stakeholders.

\section{Methods:}

Comprehensive searches were conducted on stakeholders' websites and 11 electronic databases for existing concepts of a smart nursing home (Phase 1), and on what and how technologies and medical services were implemented in nursing home settings, as well as acceptability assessment by the stakeholders (Phase 2). The publication year was inclusive of January 1999 to September 2021. The language was limited to English and Chinese. Included articles must report nursing home settings and related to older adults $\geq 60$ years old with or without medical demands but not bedbound. New technology developments and system designs were measured by Technology Readiness Levels. The analysis was guided by Framework Method and the smart technology adoption behaviours of elder consumers theoretical model, and reported according to the PRISMA-ScR.

\section{Results:}

A total of 177 literature (13 website documents and 164 journal articles) were selected. Smart nursing homes are technology-assisted nursing homes that allow life enjoyment of its residents. They used loT, computing technologies, cloud computing, big data and Al, information management systems, and digital health to integrate medical services in monitoring abnormal events, assisting daily living, teleconsultation, health information management, and improving interaction between providers and residents. Fifty-five percent of the new technologies were proven ready for use in nursing homes (level 6-7), and the remaining were proven of implementation feasibility (level 1-5). Providers with higher education, tech-savviness, fewer years at work, and older adults with more severe illnesses were more acceptable to smart technologies.

\section{Conclusions:}

Smart nursing homes with integrated medical services have great potential to improve the quality of care and ensure elderly residents' quality of life.

\section{Introduction}

Ageing population is associated with increased demand in healthcare and they would require a wide range of assistance in physical mobility and daily monitoring (1). However, smart technologies could help older adults extend their independent existence and well-being (2). In the earlier stage, a large number of sensors and actuators were used as a ubiquitous environment (u-healthcare) to monitor patients (3). The term 'smart' was initiated by IBM's (International Business Machines Corporation) concept of 'Smarter Planet' (4), and later, it was associated with a range of information technologies such as the Internet of Things (IoT), big data, cloud computing, and artificial intelligence (Al) in the medical field (5). The World Health Organisation (WHO) (2019) links smart healthcare with digital health including telemedicine and mobile health (6).

Smart technologies empower older adults to 'live in place' and meet their needs, so that they can lead active, fulfilling, and good life (7). Several studies have proved that smart technologies were feasibly applied in health monitoring, disease prediction, and detection of anomalous situations for home-based care residents $(8,9)$. However, admission to nursing homes is usually a major life event for most older adults due to the changes in health conditions with complex needs in healthcare (10). Using smart technology in nursing home settings could provide a more comfortable and safe environment for its residents (11). Nursing homes that integrate smart technologies could benefit caregivers by saving time and reducing unnecessary workload while providing efficient and effective care services for their residents, such as using wearable devices to collect biometric data (12). Moreover, it is possible to reduce healthcare costs by using more efficient healthcare resources (13).

Globally, the quality of care in most nursing homes is suboptimal, and the concerns are about the shortages of doctors and nurses, skills of nursing home staff, and safety of medical operation (14-16). To cope with the challenges related to ageing population, many nations are seeking solutions for alternative senior care and encouraging innovation in real-time monitoring of diseases, mobile phone-based healthcare assistance, electronic health record, and telemedicine at nursing homes (17). As one of the countries in the world facing the 'grey tsunami', the Chinese Ministry of Civil Affairs, a supervision department of nursing homes initiated a report to promote loT-based projects for institutional senior care. These pilot projects include health monitoring, fall detection and location tracking, and any innovation on big data management or analysis would be supported financially (18). However, a clear concept of nursing homes and the 'smartness' of technology is yet to be defined $(19,20)$.

Accordingly, a scoping review is needed to provide a novel nursing home model which includes a definition of smart nursing homes, and the availability of smart technologies to meet the demands and aspirations of potential customers, such as older adults and their family members. Standardising the definition and scope of smart nursing home services would help future initiatives and the introduction of smart technologies in the nursing home settings. This would also allow evaluation and monitoring of smart nursing homes operation to have an evidence-based reference in 
terms of scopes of nursing care services, information technologies, acceptability to the older adults, family members, nursing home staff, and nursing home stakeholders (21).

\section{Theoretical model}

The smart technology adoption behaviours of elder consumers theoretical model by Golant (2017) is adopted to guide this scoping review (Figure 1) (22). The model offers an adequate explanation of the technology appraisals of older adults with regard to adopting smart technologies. The coping process may come from the older adults' unmet needs, the user perspective of perceived efficaciousness, usability, and collateral damages until the stage of making a decision to adopt the 'new' solution. This coping process is also influenced by the internal information (potential users' past experiences) and external information such as the persuasiveness of friends, family members, and doctors pertaining to the technology. The coping process may be affected by other factors such as user sociodemographic characteristics. The non-senior stakeholders, for example, the healthcare professionals (HCPs) may have the same coping process when they consider the unmet needs of the older adults. This model is appropriate in formulating the review objectives.

\section{Review objectives}

This scoping review was conducted to systematically map the existing smart concepts and smart healthcare technologies within nursing home settings to examine the qualitative evidence on technological feasibility, integration of medical services, and acceptability of a smart nursing home by all stakeholders including the older adults aged $\geq 60$ years old and their caregivers (23).

\section{Method}

Extended and comprehensive searches were conducted on stakeholder websites for existing concepts of a smart nursing home and criteria of its services (Phase 1). The search was continued on the 11 electronic databases for technologies and medical services that were implemented in nursing home settings, as well as the acceptability as reported by stakeholders including nursing home residents and healthcare professionals (Phase 2). Technology Readiness Level (TRL) was adopted to evaluate the feasibility of technologies and measure the maturity of a particular technology or the consistent comparison of maturity between different types of technology (24). The analysis was guided by the Framework Method (25) and the smart technology adoption behaviours of elder consumers theoretical model (22). Results were reported according to the PRISMA-ScR (26) (Related File 1).

\section{Eligibility criteria}

The eligibility criteria include: 1) concepts or definitions of a smart nursing home; 2) nursing home residents aged 60 years old or above with or without medical demands but not bed-bound; 3 ) assessment of any type of health information technologies, models that were considered 'smart' in nursing home settings; 4) perception and acceptability of smart nursing homes by the older adults and other stakeholders; 5) challenges and recommendations to implement information technologies that facilitate medical services in nursing homes. Other articles were irrelevant to the study objective and nursing homes, or the smart technologies in entertainment, environmental control, transportation, were excluded.

\section{Information sources and search strategy}

Following the plan of the published study protocol (20), an extended search on stakeholder websites for the statement of smart nursing homes was conducted on three popular search engines: 'Google', 'Yahoo' and 'Baidu (a Chinese engine)' using English and Chinese keywords 'nursing home', 'Yang Lao Yuan' (미), and 'retirement home' and followed by 'smart nursing home', 'concept of smart nursing home', 'definition of smart nursing home' and 'criteria of smart nursing home' or 'standard of smart nursing home' sequentially.

Additionally, the keywords: smart nursing home, smart health*(care), Internet of Things (loT), digital health*, remote health*(care), telemedicine, mobile health*(care), mHealth (including telemedicine), eHealth, point-of-care, wireless sensor network (WSN), artificial intelligence (Al) and ubiquitous healthcare (u-healthcare) were used for searching the published articles on technological feasibility and user acceptance or acceptability in nursing homes on the English bibliographic databases (PubMed, IEEE Explore, CINAHL, Scopus, Cochrane Library, Health Systems Evidence, Social Systems Evidence, ProQuest Dissertations \& Theses Global, Psychology and Behavioral Sciences Collection). The keywords applied on the selected

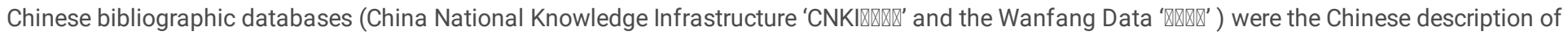
smart nursing homes, for example, language was limited to English and Chinese. The publication year was limited to those published between January 1999 and May 2020 as the label 'smart dust' to wireless sensor networks was first given in 1999 (27). Additional File 1 provides the search strategy on databases. An updated search was conducted on the 11 bibliographic databases by applying the same strategy to identify the latest publication from May 2020 to September 2021. Due to the license from the university, the search on Scopus was updated to December 2019.

\section{Selection of sources of evidence}

A comprehensive screening of eligible articles was conducted by a reviewer (YYZ). All sources were imported into the Endnotes $\mathrm{X} 9$ library and the duplicates have been removed. Endnotes X9 library was shared with a second reviewer (NKD). Documents in the Chinese language were double 
reviewed by another reviewer (JS). Eligible criteria were applied to both abstracts and full-texts. Quality appraisal of individual sources of evidence was not done because this scoping review was conducted to provide an overview of the existing evidence of smart nursing home concepts,

technological feasibility, medical services integration, and acceptability of a smart nursing home regardless of methodological quality or risk of bias (26). In the selection process, any disagreements between two reviewers were addressed by consulting the third reviewer (FKR, SSG and BHC).

\section{Data charting}

The Framework Method was used to guide the process of data analysis by applying codes, categorising themes, and summarising the results (20). The data from stakeholder websites and electronic databases were categorised by type of technology related to 'smartness', the function of technology, direct user, integrated medical services, and stakeholder acceptability. The textual statements on the concept of smart nursing homes, integration of medical services, and acceptability of the stakeholders were extracted by three investigators (YYZ, NKD and JS). Preliminary codes and themes related to the research objectives were named after the most frequently recurring terms within the same clusters, and those names were given by the generalisability of textural data. Data extraction and translation from Chinese to English were also done (YYZ). The individual data extraction and analysis were subsequently discussed by all investigators (YYZ, FKR, SSG and BHC). The coding categories were defined and refined until the consensus was reached among at least three of the four investigators.

\section{Results}

A total of 177 literature (Figure 2 and Additional File 2) were selected for review comprising 13 documents from websites and 164 articles from the bibliographic databases.

\section{Phase 1: Definition, concepts and criteria of a smart nursing home}

Thirty documents and articles (Additional File 2) were selected from which information on the definition, concepts, and criteria of a smart nursing home was retrieved. Of these, 13 documents were selected from the stakeholder websites in Phase 1, and the other 17 articles were research papers searched in Phase 2. The sources of the 13 documents from stakeholder websites were government authorities $(n=4)$, smart technology providers $(n=4)$, home pages of nursing home $(n=3)$, construction company of nursing home $(n=1)$, and respective research institute $(n=1)$.

The qualitative analysis generated 3 themes related to the concept (Table 1): 1) application of smart technologies, 2) technology-assisted nursing care, and 3) combination of smart home and hospital models. In addition, quality of care (QoC) defined by WHO (28) was adopted and applied to measure the criteria and outcome of smart nursing home services that are provided to its residents. In order to achieve better services, health care must be safe, effective, timely, efficient, equitable, and people-centered (28).

Based on the qualitative analysis, we defined a smart nursing home as a collective or individual senior care model that integrates tending of life routines and healthcare needs of its residents with information technologies or engineering that may provide continuous monitoring to its residents, connected communication within its care providers, and teleconsultation with external medical resources. Technology-assisted nursing care ensures life enjoyment in an affordable and safe environment, and immediate health attention with people-centered care that is effective, efficient, and evidence-based. Additional File 3 presents the quotations and the categories of the code.

\section{Phase 2: Technological feasibility, integration of medical services and acceptability}

A total of 164 articles from 28 countries and regions across four continents were eligible for data extraction. Two of the 164 articles including an editorial on bringing smart technologies into a nursing home (29) and one system design of engineering methodology (30) were only eligible to be included in Phase 1 for exacting the definition of smart nursing homes. There were 162 articles reviewed in Phase 2 (Table 2). Out of these, 50\% $(n=81)$ were studies on system designs, $7 \%(n=12)$ experimental, 23\% $(n=38)$ non-experimental, $8 \%(n=13)$ qualitative studies, 3\% $(n=4)$ mixed methods, $9 \%(n=14)$ non-research articles including literature reviews, perspective, and editorial. Fifty-seven percent ( $n=93)$ were journal articles, 31\% $(n=50)$ conference papers, $9 \%(n=15)$ student dissertations/theses and $3 \%(n=4)$ book chapters. Major resources were from China including Taiwan $(n=41)$, and the USA $(n=40)$.

\section{Technologies related to 'smartness'}

Out of 162 articles, $41 \%$ articles $(n=66)$ were on loT, 35\% ( $n=57)$ on digital health, $12 \%(n=20)$ on information management system (IMS), 8\% ( $n=13$ ) on big data and $\mathrm{Al}, 3 \%(\mathrm{n}=5)$ on computing technologies and $1 \%(n=1)$ on cloud computing. The technology smartness offers much more interaction between the nursing home resident and HCPs, enhances safety, and improves quality of care $(11,31)$.

\section{Function of smart technologies in nursing home settings and direct users}

Forty-seven percent of included articles $(n=76)$ reported technologies on monitoring and notification of abnormal events such as health monitoring, fall detection, and location tracking, $35 \%$ of articles $(n=57)$ on remote clinical services through digital health, 12\% ( $n=20)$ on information management and decision making, $3 \%(n=5)$ on clinical data analysis by Al approach, and $3 \%(n=4)$ on daily living assistance. The direct users of 
those smart technologies were nursing home residents $(n=132)$ and HCPs $(n=30)$, such as nursing home staff and health professionals in remote hospitals which provided health services for nursing homes. There was none related to family members as the direct users.

Monitoring and notification of abnormal events: Monitoring devices have been proven to ensure the safety of the nursing home residents in fall prevention (32-45), automatic monitoring of health conditions, and notification of emerging events such as heart attacks and fatal accidents (11, $12,19,31,46-103)$. The vital sign of older adults could be collected and recorded by the wearable devices such as clothes and shoes on nursing home residents $(35,95)$. Sensors were installed in the mattresses and rooms to monitor the behaviours and sleeping quality of older adults, especially used for the residents with limited mobility $(80,90)$. Biosensors, ultrasonic sensors, infrared sensors, radio frequency identification (RFID), GPS were mainly used with loT terminals $(63,68,74,77)$. Cameras, mobile devices, and personal computers were embedded with sensor networks to assist the real-time monitoring, and family members could also be given access to the real-time monitoring of their senior family members in the nursing homes (34). Such a solution improved care efficiency and decision-making from nursing home HCPs, especially in managing a high number of residents and older adults with cognitive disorders (85).

Remote clinical services through digital health: Digital health including telemedicine and mHealth has shown to benefit the older adults at the nursing homes in rural areas with good internet or communication coverage (104-133). During the COVID-19 pandemic, telemedicine was shown to reduce unnecessary hospitalisation $(134,135)$. Electronic stethoscopes, otoscopes, dermascopes, dental scopes, and electrocardiograms could also be implemented through the internet and live video, and the digital images of residents could be transmitted in real-time to hospital specialists (136). Telehealth and mHealth were widely applied in managing cognitive disorders (137-140), dermatologic conditions (141-143), cardiovascular diseases $(107,115,144)$, diabetes mellitus $(145)$, rehabilitation of disabilities $(31,146)$, dentistry $(147)$ and ophthalmology $(148)$ in distance. The portable X-ray machine attached with mobile devices were successfully conducted $\mathrm{x}$-ray for nursing home residents to reduce unnecessary transmission to the hospitals, and the services were of comparable quality to hospital-based examinations (149-154). Telemedicine with designed software helped doctors to prescribe medicines remotely and avoid adverse drug events $(155,156)$.

Information management and decision making: There was a growing use of electronic documentation in many nursing homes requiring proper information management for patients' medical records, nursing projects management, care quality assessment, clinical task schedule, and medication records (157-161). The health information of nursing home residents was manually collected by nursing home staff or through technology-based devices such as mobile phones, tablets, personal computers, and sensors to input into the electronic medical records (EMR) systems $(162,163)$. The information management systems also improved clinical decision-making by sharing and tracking patients' medical records and enhanced HCPs' communication to reduce errors in clinical practices (163-176).

Clinical data analysis by Al: Al approach helped with health-related parameter analysis and big data management (177, 178) Using Al to analyse biometric data collected from older adults enabled the identification of potential relationships between parameters and frailty (179, 180). As an emerging technology, big data analytic, data mining, and classification using in nursing home management would transform the available data into structured knowledge, enhance data reliability, and enable accurate diagnosis such as detection of disuse syndrome (78).

Activities of daily living (ADLs) assistance: Based on the loT and computing technologies, smart toolkits had been developed to assist older adults with chronic diseases in their activities of daily living for example smart pill-boxes with automagical medication reminders, recording, and pilldispensing that assisted them in taking their daily medications that improved medication adherence (181-183). Humanoid robots were developed to monitor nursing home residents' activities and ensure their safety in certain areas (184).

\section{Technology Readiness Level (TRL) measurement}

TRL classifies 9 levels of developmental stages from basic principles and technology concepts formulated to the actual system completed and proved (185). Of the 81 articles on system designs, three (Chen et al., 2021; Danielsen, 2016; Montanini et al., 2017) were not able to be evaluated by TRLs because these were only abstracts with inadequate information, $6.5 \%(n=5)$ were judged to be at level $1,15 \%(n=12)$ at level $2,14 \%(n=11)$ at level 3, 6.5\% $(n=5)$ at level $4,4 \%(n=3)$ at level 5, 19\% $(n=15)$ at level 6 , and 35\% $(n=27)$ at level 7 (Table 3). Among newly developed technologies, $82 \%(n=64)$ were applications used for health and abnormal events monitoring, fall detection, and notification systems. The remaining $18 \%$ ( $n=14)$ were related to activities of daily living assistance, information management, big data analysis, and remote clinical services.

Integration of medical services

There were 44 out of 162 articles that reported the integration of medical services in nursing homes. Telemedicine (31/44, 70\%), mHealth (10/44, $23 \%)$, and clinical information management $(3 / 44,7 \%)$ were used to integrate medical services from distant hospitals and clinical specialists to assist the nursing homes (Table 4 and Additional File 4).

Integration of medical services in telemedicine: The integration of medical services was widely used in the field of telemedicine for example videoconferencing $(16 / 31,52 \%)$, telemonitoring (8/31, 26\%), information technologies (5/31, 16\%), and remote specialist decision making (2/31, $6 \%$ ) have been integrated to overcome the issues of accessibility and timeliness of medical services for nursing home residents. As a form of telemedicine, teleconsultation that integrated real-time videoconference conducted on videophones or computers combined with cameras and microphones was applicable to replace face-to-face consultations in nursing homes, and it enhanced clinical efficiency and cost-effectiveness of healthcare delivery $(109,136,137,186)$. Teleconsultation that integrated health monitoring devices such as mobile phones or smartwatches

Page 5/36 
provided a telemonitoring service by electronically recording heart rate and blood pressure, and it could enable prompt response and management of urgent health conditions that raised in the older adults in remote nursing homes $(19,43,53,90,123,176)$. Telemedicine integrated computing technologies have been shown to help remote HCPs make good decisions in clinical management after reviewing patients' digital health records which were shared through emails or web-based health management systems $(112,140-143)$.

Integration of medical services through mHealth: Monitoring abnormal events $(31,34,69,78)$, radiography $(130,151,187)$ and teleconsultation $(116$, $146,148)$ could be implemented through mobile devices. mHealth personalised nursing home services, improved efficiency in terms of a closer connection between HCPs and nursing home residents, lowered incidences of unnoticed events, and ensured the quality of life (156). Mobile devices that connected with sensor-based devices enabled HCPs to monitor and interact with older adults in real-time, and abnormal events such as activities related to falls would be reported to prevent (78). Mobile applications could assist HCPs at point-of-care to schedule clinical tasks, perform radiography, digitally record their clinical practices that resulting in time-saving and error reduction (130). Besides, personal mobiles or tablets were used to connect nursing home residents to conduct teleconsultation (116).

Integration of clinical information: Integration of clinical information could improve the quality of care in different medical organisations, for example, sharing patients' clinical information between nursing homes and differently external care departments such as the department of pathology, pharmacy, physical therapy, and other social agents increased valuable support for nursing care, enhanced coordination with multiple specialty consultants, and improved administrative practices $(159,163)$.

\section{Stakeholders' acceptability}

Guided by the theoretical model proposed by Golant (2017) (22), we observed both the expected and unexpected reasons of stakeholders' acceptability of smart technologies. In addition, individual attributes are associated with the adoption of smart solutions (Table 5 and Additional File 5).

Persuasiveness of external information and internal information: Older adults became more aware and were willing to use new technology when they felt persuaded or compelled of the potential benefit of the technology from external resources such as their family members or healthcare providers $(32,188)$. This coping process is also influenced by internal information such as user experienced helpfulness, ease of use, and presence of safety features of the technology $(120,150)$. These factors resulted in user satisfaction, enhanced positive attitudes, and final adoption of smart technologies $(59,107)$.

The perceived efficaciousness: The nursing home residents who had experienced or perceived how smart technologies usefulness to meet their healthcare needs and demands were more acceptable to the technologies (49). Similarly, HCPs perceived helpfulness in assisting care delivery and care efficiency that increased their acceptability of smart technology for example using health information exchange systems efficiently improved doctor-patient communication (159). Using smart technologies to enhance HCPs' daily routines, improve medication safety, and deal with the events of emergency could be a better solution to improve the quality of care and ensure the older adults' quality of life $(105,156)$.

Perceived usability (positive and negative): Smart technology improved access to healthcare for nursing home residents (150). The users increased their awareness and consideration of adopting smart technologies when they recognised that smart solutions would be necessary for care (67, 121$)$. The appraisals of ease of use or ease to learn with the new technology $(112,120,142)$, user-friendly $(63,142,165)$, and convenience $(106,146)$ in coping process that enhanced user acceptability to the new smart technological solutions. Users also preferred the "human-centric" designs to fit their lifestyles $(32,89)$. The affordability of smart technology is one of the considerations in coping process for example the smart solution would be better accepted if the cost was not too costly or if not more expensive than the conventional care model (32). Adequate tech support and regular training were expected to support new technology user engagement, confidence, and continuous operation $(165,186)$. In addition, the appropriate domestication of new technology could improve user acceptability (125). Domestication is a dynamic process when users in a variety of environments adapt and start to use the new technologies (189).

In contrast, appraisals of unusefulness or uncertainty of usefulness of a smart solution $(120,142)$, not easy to use or to learn (190, 191$)$, lacking in supportive resources $(132,172)$ or tech-support $(167)$ were reported to negatively affect the user acceptability. Some HCPs perceived new technologies as a burden when they disrupted routines or brought added workloads, reducing their time to provide essential nursing care for the residents. For example, when initiating a new information system that required manual input of residents' health records into the system caused frustrations among the HCPs $(63,173)$.

Perceived collateral damages: Potential medical risks, sensitivity or reliability of technology, errors during the operation, and increased costs were the main concerns that have been reported $(120,121,188)$ to associated with the unintended and harmful effects of using smart technology $(22)$.

Acceptability differs by the attributes of residents and HCPs: Attributes of residents and HCPs were found to be associated with the acceptability and adoption of new technologies. The attribute of residents identified from the reviewed articles was the severity of illness (63). The positive attributes of HCPs in accepting new technological solutions in nursing homes were higher educational attainment (108), a few of year working experience, and tech-savviness $(49,112,156)$. 


\section{Discussion}

To the best of our knowledge, this is the first scoping review that identified the gaps and scope of evidence on the concept of a smart nursing home, explored the smart technologies to be used in nursing home settings, and described medical services that could be integrated and implemented in nursing homes. We evaluated the feasibility of innovative technologies in development by applying the TRLs. This review has also captured the stakeholders' acceptability of the smart technologies, especially from the older adults and HCPs perspectives.

In previous studies, a smart nursing home was seen as a smart building equipped with loT technologies (177). Our review concurs and notes that health status and emergency situations of nursing home residents were mainly monitored and collected by sensors through wearable devices, and the sensors installed on walls less on the user themselves achieved comfort and safe environment $(11,86)$. In particular, a smart nursing home would offer technology-assisted nursing care for older adults with the needs of health monitoring, activities of daily living, and safety $(96,192)$. Based on this, a comprehensive concept of smart nursing homes has to be supported by smart technologies to provide integrated nursing care, personalised monitoring of abnormal events, and assistance in activities of daily living. This smart nursing home model also emphasises the integration of medical services from remote clinical specialists and hospitals to support nursing and medical cares that are convenient, comfortable, and safe to the residents (11). As a result, the services in smart nursing homes could be more effective and efficient in care delivery that achieve the expectations of all stakeholders including the nursing home residents, family members, and nursing home staff (12). Figure 3 illustrates the concept of a smart nursing home.

With regards to the feasibility of smart technology in nursing home settings, the wide range of technologies reported in the literature can be classified as loT, computing technologies, cloud computing, big data, and Al, information management system and digital health, and these technologies contribute to the 'smartness'. A few published articles had classified the functions of smart technology for senior care in hospital and home-based care settings, and the most important functions were identified as health status and mobility monitoring (193). In hospital settings, smart technologies were used particularly to improve clinical decision-making (21) while in home-based care, smart technologies assisted in the selfmanagement of chronic diseases and remote health monitoring $(194,195)$. In nursing homes, the feasible technologies identified were mainly used in monitoring abnormal events, connecting to remote clinical services, clinical information management, big data analysis, and devices development for assisting activities of daily living. The TRL evaluation showed that $54 \%$ of new system designs were at level 6 to level 7 which have been proven ready for use in nursing homes, and the function of technology was mainly for monitoring abnormal events. The development of these new technologies is expected to progress to the higher levels of TRL 8 and 9 to be ready for commercialisation and future public use. Therefore, the technologies supporting ageing in place have been developed more maturely and some of the applications such as health monitoring, ADLs, and safety improvement have been reached to TRL 8 and 9 (192).

The integration of medical services is a network of healthcare services and advanced technologies, and it could achieve clinical efficiency or overcome the limited access to healthcare (196). Electronic clinical information, telemedicine, and mHealth were increasingly used and shown to be successful to some extent in overcoming shortages of medical resources and improving healthcare access and the standards of clinical practices in nursing homes (132). From our scoping review, clinical information management and remote clinical services, especially telemedicine have been broadly implemented in some nursing homes, and these services were reported to be acceptable to many stakeholders (146). With the effective implementation of smart technologies and integration of medical services, many nursing homes were able in managing a large number of residents and providing customised care to older adults (93).

The literature suggested that stakeholders' acceptability of smart technologies was determined by the persuasiveness of external and internal information, perceived efficaciousness, perceived usability, and perceived collateral damages (22). These determinants were also identified and extracted from the reviewed articles. We also observed that the older adults' severity of illnesses, the users with a higher level of education and techsavviness, and the healthcare providers with fewer years of working experience (younger age) were associated with higher acceptability of smart technologies $(49,63,108,112,156)$. These findings were consistent with a literature review of older adults' acceptance of technology for ageing in place, in which the factors of technology acceptability included positive experiences with the technology such as ease of use, increased safety, and security for care, perceived need to use, the concerns of technical errors, social influence, and their physical conditions (192). However, we did not find any evidence on the older adults' unmet needs and the description of their resilience to smart technology. The older adults did not seem to take concrete actions to adopt a smart technology according to their stressful unmet needs, or the different level of resilience to adversity from the new technologies as indicated in the theoretical model (22).

There are some limitations to be aware of when using the findings in this review. Business reports were not published in the 11 selected databases which we searched on, and it might cause the review to miss the new technologies or actual systems which have been approved to use in the nursing homes (TRL 8 and 9). Nevertheless, the number and types of databases that this review has conducted searches on are believed to have captured informative literature to the review objectives. Meta-analysis and quality assessment were not applicable in this scoping review because the literature and studies informed about the scope and extent of the smart nursing home concepts, technology utilities with its integrated medical services, and acceptability by stakeholders disregarding the literature risk of biases. In the future, researchers could conduct an in-depth exploration of the characteristics and feasibility of smart technologies implemented in nursing homes by the functions that we categorised, for example, the technologies in the monitoring of abnormal events and activities of daily living assistance. 


\section{Conclusion}

Smart nursing homes with integrated medical services have great potential to be a future trend to replace the traditional nursing home. The motivation of transferring from a traditional model to a smart one includes having advanced and safe information technologies, well-trained staff who deliver the nursing care and medical services, and meeting the expectations of all stakeholders. However, technology readiness needs to catch up (clinical data analysis by Al approach and cloud computing technologies) even though much has already been presented (IoT, telemedicine, and information management system). The technology appraisal process was determined by perceived efficaciousness, perceived usability, and perceived collateral damages of adopting the smart technology. Older adults living with severe illnesses and the stakeholders who were persuaded with the information about the smart solutions from external and internal resources were more acceptable to new technological solutions in nursing homes. Meanwhile, the HCPs with higher educational attainment, fewer years of working experience, and good tech-savviness had higher acceptability of smart technologies.

The results of this scoping review are relevant to a broad base of readers who are interested in this research and to most developed and developing countries that have nursing homes. Future research on introducing smart technologies into nursing homes or developing a successful smart nursing home model could refer to the results of this scoping review for the types and scope of smart technologies that integrate multidisciplinary biomedical informatics and medical services, stakeholders' attribute preparedness, and preparation. This is applicable in the planning, evaluation and monitoring of the feasible, and functional technologies when those are integrated with different types of medical services.

\section{Abbreviations}

IoT: internet of Things; Al: artificial intelligence; HCPs: healthcare professionals; TRL: technology readiness level; ADLs: activities of daily living.

\section{Declarations}

\section{Acknowledgement}

Not Applicable

\section{Authors' contributions}

All authors were involved in the review process. YYZ proposed the task and conducted the qualitative scoping review. FZR and NKD contributed to study selection and reviewed the literature published in English. JS was involved in selecting the literature in Chinese. BHC, SGS, and FZR were involved in the thematic analysis and verified the retrieved textual data. All authors have made substantive intellectual contributions to the development of this scoping review and approved the final manuscript for submission to the journal.

\section{Protocol Registration}

The protocol of this scoping review has registered on osf.io (URL: https://osf.io/qtwz2/) and published in BMJ Open (20).

\section{Ethics Approval and Consent to Participate}

Not applicable.

\section{Consent for Publication}

Not applicable.

\section{Availability of Data and Materials}

The authors declare that all data supporting the findings of this study are already made available in the supplementary files (see additional files 1-5). If further data clarification is required, please contact the corresponding author or Ms. Yuanyuan Zhao at helenzhao78@qq.com or pcshelenzhao@gmail.com.

\section{Competing interests}

We have no conflict of interest to declare.

\section{Funding}

The author(s) received no financial support for the research, authorship and publication of this article.

\section{References}


1. Bzura C, Im H, Malehorn K, Liu W. The Emerging Role of Robotics in Personal Health Care: Bringing Smart Health Care Home. 2012.

2. Sokullu R, Akkaş MA, Demir E. loT supported smart home for the elderly. Internet of Things. 2020;11:100239.

3. Brown I, Adams AAJIRoIE. The ethical challenges of ubiquitous healthcare. 2007;8(12):53-60.

4. IBM. Smarter Planet IBM website2008 [Available from: https://www.ibm.com/ibm/history/ibm100/us/en/icons/smarterplanet/.

5. Tian S, Yang W, Grange JML, Wang P, Huang W, Ye Z. Smart healthcare: making medical care more intelligent. Global Health Journal. 2019;3(3):62-5.

6. WHO. WHO guideline: Recommendations on Digital Interventions for Health System Strengthening. World Health Organization, Geneva2019. p. P2.

7. Demiris G, Hensel BK. Technologies for an aging society: a systematic review of "smart home" applications. Yearbook of medical informatics. 2008;17(01):33-40.

8. Rantz M, Phillips LJ, Galambos C, Lane K, Alexander GL, Despins L, et al. Randomized trial of intelligent sensor system for early illness alerts in senior housing. Journal of the American Medical Directors Association. 2017;18(10):860-70.

9. Ni Q, Garcia Hernando AB, la Cruz D, Pau I. The elderly's independent living in smart homes: A characterization of activities and sensing infrastructure survey to facilitate services development. Sensors. 2015;15(5):11312-62.

10. Serow WJ. Why the elderly move: Cross-national comparisons. Research on aging. 1987;9(4):582-97.

11. Gamberini L, Fabbri L, Orso V, Pluchino P, Ruggiero R, Barattini R, et al. A cyber secured loT: Fostering smart living and safety of fragile individuals in intelligent environments. Lecture Notes in Electrical Engineering2018. p. 335-42.

12. Huang P, Lin C, Wang Y, Hsieh H, editors. Development of Health Care System Based on Wearable Devices. 2019 Prognostics and System Health Management Conference (PHM-Paris); 2019 2-5 May 2019.

13. Raja TYMVJI. Internet of Things: Benefits and Risk of Smart Healthcare Application. 2016;10(3):37-42.

14. Chu L-W, Chi IJJotAMDA. Nursing homes in China. 2008;9(4):237-43.

15. Xie W, Fan R, editors. Towards Ethically and Medically Sustainable Care for the Elderly: The Case of China. HEC Forum; 2020: Springer.

16. Tolson D, Rolland Y, Andrieu S, Aquino J-P, Beard J, Benetos A, et al. International Association of Gerontology and Geriatrics: A global agenda for clinical research and quality of care in nursing homes. Journal of the American Medical Directors Association. 2011;12(3):184-9.

17. WhiteHouse. Emerging Technologies to Support an Aging Population. USA: Committee on Technology of the National Science \& Technology Council; 2019.

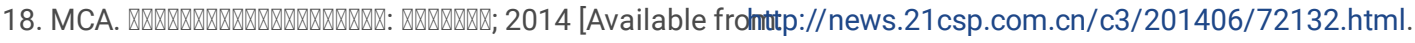

19. Wang J. $\quad$ Q

20. Zhao Y, Rokhani FZ, Ghazali SS, Chew BH. Defining the concepts of a smart nursing home and its potential technology utilities that integrate medical services and are acceptable to stakeholders: a scoping review protocol. BMJ open. 2021;11(2):e041452.

21. Mieronkoski R, Azimi I, Rahmani AM, Aantaa R, Terävä V, Liljeberg P, et al. The Internet of Things for basic nursing care-A scoping review. 2017;69:78-90.

22. Golant SMJJoAS. A theoretical model to explain the smart technology adoption behaviors of elder consumers (Elderadopt). 2017;42:56-73.

23. GOV.cn. Law of the people's republic of China on protection of the rights and interests of the elderly: The State Council, The People's Republic of China; 2012 [Available from: http://www.gov.cn/fffg/2012-12/28/content_2305570.htm.

24. Mankins JC. Technology readiness levels. White Paper, April. 1995;6:1995.

25. Gale NK, Heath G, Cameron E, Rashid S, Redwood SJBmrm. Using the framework method for the analysis of qualitative data in multi-disciplinary health research. 2013;13(1):117.

26. Tricco AC, Lillie E, Zarin W, O'Brien KK, Colquhoun H, Levac D, et al. PRISMA extension for scoping reviews (PRISMA-ScR): checklist and explanation. 2018;169(7):467-73.

27. Kahn JM, Katz RH, Pister KS, editors. Next century challenges: mobile networking for "Smart Dust". Proceedings of the 5th annual ACM/IEEE international conference on Mobile computing and networking; 1999.

28. WHO. What is Quality of Care and why is it important? [Available from: https://www.who.int/teams/maternal-newborn-child-adolescent-healthand-ageing/quality-of-care.

29. Morley JE. High Technology Coming to a Nursing Home Near You. Journal of the American Medical Directors Association. 2012;13(5):409-12.

30. Cui F, Ma L, Hou G, Pang Z, Hou Y, Li L. Development of smart nursing homes using systems engineering methodologies in industry 4.0. Enterprise Information Systems. 2018.

31. Delmastro F, Dolciotti C, Palumbo F, Magrini M, Di Martino F, La Rosa D, et al., editors. Long-term care: How to improve the quality of life with mobile and e-health services. International Conference on Wireless and Mobile Computing, Networking and Communications; 2018.

32. Abbate S, Avvenuti M, Light J. Usability study of a wireless monitoring system among Alzheimer's disease elderly population. International journal of telemedicine and applications. 2014;2014.

Page 9/36 
33. Dias PVGF, Costa EDM, Tcheou MP, Lovisolo L, editors. Fall detection monitoring system with position detection for elderly at indoor environments under supervision. 2016 8th IEEE Latin-American Conference on Communications, LATINCOM 2016 ; 2016.

34. Donnelly S, Reginatto B, Kearns O, Mc Carthy M, Byrom B, Muehlhausen W, et al. The Burden of a Remote Trial in a Nursing Home Setting: Qualitative Study. Journal of medical Internet research. 2018;20(6):e220.

35. Mahfuz S, Isah H, Zulkernine F, Nicholls P, editors. Detecting Irregular Patterns in loT Streaming Data for Fall Detection. 2018 IEEE 9th Annual Information Technology, Electronics and Mobile Communication Conference (IEMCON); 2018 1-3 Nov. 2018.

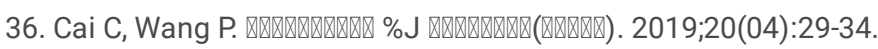

37. Q

38. Toda K, Shinomiya N, editors. Machine learning-based fall detection system for the elderly using passive RFID sensor tags. Proceedings of the International Conference on Sensing Technology, ICST; 2019.

39. Buisseret F, Catinus L, Grenard R, Jojczyk L, Fievez D, Barvaux V, et al. Timed Up and Go and Six-Minute Walking Tests with Wearable Inertial Sensor: One Step Further for the Prediction of the Risk of Fall in Elderly Nursing Home People. Sensors (Basel, Switzerland). 2020;20(11).

40. Chen W, Wang X, Chen J, Ding Z, Li J, Li B. An Alarm System Based on BP Neural Network Algorithm for the Detection of Falls to Elderly Person. Lecture Notes of the Institute for Computer Sciences, Social-Informatics and Telecommunications Engineering, LNICST2021. p. 571-81.

41. Gharti P, editor A study of fall detection monitoring system for elderly people through IOT and mobile based application devices in indoor environment. 2020 5th International Conference on Innovative Technologies in Intelligent Systems and Industrial Applications (CITISIA); 2020 25-27 Nov. 2020.

42. Lee SK, Ahn J, Shin JH, Lee JY. Application of Machine Learning Methods in Nursing Home Research. International journal of environmental research and public health. 2020;17(17).

43. Mishkhal I, Sarah Abd ALK, Hassan Hadi S, Alqayyar A. Deep Learning with network of Wearable sensors for preventing the Risk of Falls for Older People. IOP Conference Series Materials Science and Engineering. 2020;928(3).

44. Suzuki M, Yamamoto R, Ishiguro Y, Sasaki H, Kotaki H. Deep learning prediction of falls among nursing home residents with Alzheimer's disease. Geriatrics \& gerontology international. 2020;20(6):589-94.

45. Wan HC, Chin KS. Exploring internet of healthcare things for establishing an integrated care link system in the healthcare industry. International Journal of Engineering Business Management. 2021;13.

46. Suzuki R, Otake S, Izutsu T, Yoshida M, Iwaya T. Monitoring daily living activities of elderly people in a nursing home using an infrared motiondetection system. Telemedicine Journal and e-Health. 2006;12(2):146-55.

47. Fischer M, Lim YY, Lawrence E, Ganguli LK, editors. ReMoteCare: Health Monitoring with Streaming Video. 2008 7th International Conference on Mobile Business; 2008 7-8 July 2008.

48. Lin YJ, Su MJ, Chen HS, Lin Cl, editors. A study of integrating digital health network with UPnP in an elderly nursing home. 13th IEEE Asia-Pacific Computer Systems Architecture Conference, ACSAC 2008; 2008.

49. Betgé-Brezetz S, Dupont MP, Ghorbel M, Kamga GB, Piekarec S, editors. Adaptive notification framework for smart nursing home. Proceedings of the 31st Annual International Conference of the IEEE Engineering in Medicine and Biology Society: Engineering the Future of Biomedicine, EMBC $2009 ; 2009$.

50. Biswas J, Jayachandran M, Shue L, Gopalakrishnan K, Yap P. Design and trial deployment of a practical sleep activity pattern monitoring system. Lecture Notes in Computer Science (including subseries Lecture Notes in Artificial Intelligence and Lecture Notes in Bioinformatics)2009. p. 190-200.

51. Hu F, Xiao Y, Hao Q. Congestion-aware, loss-resilient bio-monitoring sensor networking for mobile health applications. IEEE Journal on Selected Areas in Communications. 2009;27(4):450-65.

52. Fraile JA, Bajo J, Corchado JM, Abraham A. Applying wearable solutions in dependent environments. IEEE Transactions on Information Technology in Biomedicine. 2010;14(6):1459-67.

53. Pallikonda Rajasekaran M, Radhakrishnan S, Subbaraj P. Sensor grid applications in patient monitoring. Future Generation Computer Systems. 2010;26(4):569-75.

54. Gower V, Andrich R, Braghieri P, Susi A. An advanced monitoring system for residential care facilities. Assistive Technology Research Series2011. p. 57-64.

55. Lee S, Kim J, Lee M. The design of the m-health service application using a Nintendo DS game console. Telemedicine journal and e-health : the official journal of the American Telemedicine Association. 2011;17(2):124-30.

56. Sun Y. Human daily activity detect system optimization method using Bayesian network based on wireless sensor network. Advances in Intelligent and Soft Computing2011. p. 721-5.

57. Wu M, Huang W, editors. Health care platform with safety monitoring for long-term care institutions. The 7th International Conference on Networked Computing and Advanced Information Management; 2011 21-23 June 2011. 
58. Back I, Kallio J, Perala S, Makela K. Remote monitoring of nursing home residents using a humanoid robot. Journal of telemedicine and telecare. 2012;18(6):357-61.

59. Chang YJ, Chen CH, Lin LF, Han RP, Huang WT, Lee GC. Wireless sensor networks for vital signs monitoring: Application in a nursing home. International Journal of Distributed Sensor Networks. 2012;2012.

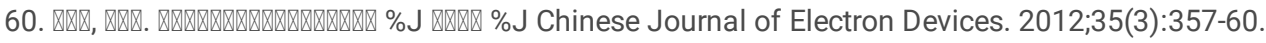

61. Nijhof N, Van Gemert-Pijnen JEWC, De Jong GEN, Ankoné JW, Seydel ER. How assistive technology can support dementia care: A study about the effects of the IST Vivago watch on patients' sleeping behavior and the care delivery process in a nursing home. Technology and Disability. 2012;24(2):103-15.

62. Ghorbel M, Betgé-Brezetz S, Dupont MP, Kamga GB, Piekarec S, Reerink J, et al. Multimodal notification framework for elderly and professional in a smart nursing home. Journal on Multimodal User Interfaces. 2013;7(4):281-97.

63. Huang J, Wang T, Su T, Lan K, editors. Design and deployment of a heart rate monitoring system in a senior center. 2013 IEEE International Conference on Sensing, Communications and Networking (SECON); 2013 24-27 June 2013.

64. Matsui T, Yoshida Y, Kagawa M, Kubota M, Kurita A. Development of a practicable non-contact bedside autonomic activation monitoring system using microwave radars and its clinical application in elderly people. Journal of clinical monitoring and computing. 2013;27(3):351-6.

65. Neuhaeuser J, D'Angelo LT. Collecting and distributing wearable sensor data: an embedded personal area network to local area network gateway server. Conference proceedings : Annual International Conference of the IEEE Engineering in Medicine and Biology Society IEEE Engineering in Medicine and Biology Society Annual Conference. 2013;2013:4650-3.

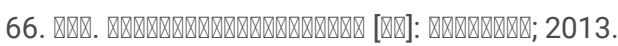

67. Tseng KC, Hsu CL, Chuang YH. Designing an intelligent health monitoring system and exploring user acceptance for the elderly. Journal of medical systems. 2013;37(6):9967.

68. 재,

69. Liu YW, Hsu YL. Developing a bed-centered nursing home care management system. Gerontechnology. 2014;13(2):108-9.

70. Zhu X, Zhou X, Chen W, Kitamura K, Nemoto T, editors. Estimation of Sleep Quality of Residents in Nursing Homes Using an Internet-Based Automatic Monitoring System. 2014 IEEE 11th Intl Conf on Ubiquitous Intelligence and Computing and 2014 IEEE 11 th Intl Conf on Autonomic and Trusted Computing and 2014 IEEE 14th Intl Conf on Scalable Computing and Communications and Its Associated Workshops; 2014 9-12 Dec. 2014.

71. Andò B, Baglio S, Lombardo CO, Marletta V, editors. A multi-user assistive system for the user safety monitoring in care facilities. 2015 IEEE International Workshop on Measurements \& Networking (M\&N); 2015 12-13 Oct. 2015.

72. Carvalho CMA, Rodrigues CAP, Aguilar PAC, De Castro MF, Andrade RMC, Boudy J, et al., editors. Adaptive tracking model in the framework of medical nursing home using infrared sensors. 2015 IEEE Globecom Workshops, GC Wkshps 2015 - Proceedings; 2015.

73. Yu X, Weller P, Grattan KTV. A WSN healthcare monitoring system for elderly people in geriatric facilities. Studies in health technology and informatics2015. p. 567-71.

74. Danielsen A. Non-intrusive bedside event recognition using infrared array and ultrasonic sensor. Lecture Notes in Computer Science (including subseries Lecture Notes in Artificial Intelligence and Lecture Notes in Bioinformatics)2016. p. 15-25.

75. Lopez-Samaniego L, Garcia-Zapirain B. A Robot-Based Tool for Physical and Cognitive Rehabilitation of Elderly People Using Biofeedback. International journal of environmental research and public health. 2016;13(12).

76. Ansefine KE, Muzakki, Sanudin, Anggadjaja E, Santoso H, editors. Smart and wearable technology approach for elderly monitoring in nursing home. 2017 IEEE 3rd International Conference on Engineering Technologies and Social Sciences (ICETSS); 2017 7-8 Aug. 2017.

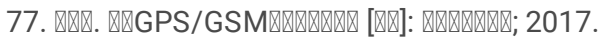

78. Mendes S, Queiroz J, Leitao P, editors. Data driven multi-agent m-health system to characterize the daily activities of elderly people. Iberian Conference on Information Systems and Technologies, CISTI; 2017.

79. Mendoza MB, Bergado CA, De Castro JLB, Siasat RGT, editors. Tracking system for patients with Alzheimer's disease in a nursing home. IEEE Region 10 Annual International Conference, Proceedings/TENCON; 2017.

80. Montanini L, Raffaeli L, de Santis A, del Campo A, Chiatti C, Paciello L, et al. Supporting caregivers in nursing homes for Alzheimer's disease patients: A technological approach to overnight supervision. Communications in Computer and Information Science2017. p. 1-19.

81. Saod AHM, Ghani SJAM, Harron NA, Ramlan SA, Rashid ANA, Ishak NH, editors. Android-based elderly support system. 2017 IEEE Symposium on Computer Applications \& Industrial Electronics (ISCAIE); 2017 24-25 April 2017.

82. Singh D, Kropf J, Hanke S, Holzinger A. Ambient assisted living technologies from the perspectives of older people and professionals. Lecture Notes in Computer Science (including subseries Lecture Notes in Artificial Intelligence and Lecture Notes in Bioinformatics)2017. p. 255-66.

83. Wu Y, Liu L, Kang J, Li L, Huang B. Measuring the wellness indices of the elderly using RFID sensors data in a smart nursing home. Lecture Notes in Computer Science (including subseries Lecture Notes in Artificial Intelligence and Lecture Notes in Bioinformatics)2017. p. 66-73.

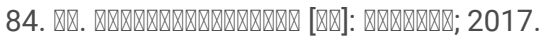

Page 11/36 
85. Bleda AL, Maestre R, Beteta MA, Vidal JA, editors. AmICare: Ambient Intelligent and Assistive System for Caregivers Support. Proceedings - 16th International Conference on Embedded and Ubiquitous Computing, EUC 2018; 2018.

86. Lee S, Shin I, Lee N, editors. Development of loT based Smart Signage Platform. 2018 International Conference on Information and Communication Technology Convergence (ICTC); 2018 17-19 Oct. 2018.

87. Morita T, Taki K, Fujimoto M, Suwa H, Arakawa Y, Yasumoto K, editors. BLE Beacon-based Activity Monitoring System toward Automatic Generation of Daily Report. 2018 IEEE International Conference on Pervasive Computing and Communications Workshops, PerCom Workshops $2018 ; 2018$.

88. Wu Y, Liu L, Li L, Lu M, Li L. Determining senior wellness status using an intelligent system based on wireless sensor network and bioinformation. Web Intelligence. 2018;16(3):159-66.

89. Borelli E, Paolini G, Antoniazzi F, Barbiroli M, Benassi F, Chesani F, et al. HABITAT: An loT solution for independent elderly. Sensors (Switzerland). $2019 ; 19(5)$.

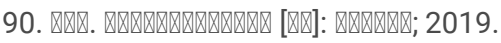

91. Fong ACM, Fong B, Hong G, editors. Short-range tracking using smart clothing sensors : AA case study of using low power wireless sensors for pateints tracking in a nursing home setting. 2018 IEEE 3rd International Conference on Communication and Information Systems, ICCIS 2018; 2019.

92. Ghosh N, Maity S, Maity K, Saha S, editors. Non-Parametric Learning Technique for Activity Recognition in Elderly Patients. TENCON 2019 - 2019 IEEE Region 10 Conference (TENCON); 2019 17-20 Oct. 2019.

93. Lenoir J. Effective User Interface of IoT System at Nursing Homes. Communications in Computer and Information Science2019. p. 490-8.

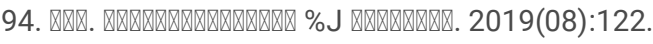

95. Takahashi K, Kitamura K, Nishida Y, Mizoguchi H, editors. Battery-less shoe-type wearable location sensor system for monitoring people with dementia. Proceedings of the International Conference on Sensing Technology, ICST; 2019.

96. Tang V, Choy KL, Ho GTS, Lam HY, Tsang YP. An loMT-based geriatric care management system for achieving smart health in nursing homes. Industrial Management and Data Systems. 2019;119(8):1819-40.

97. Xiao B.

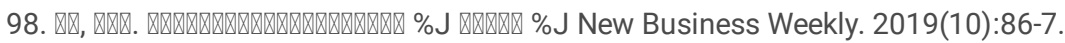

99. Yoo B, Muralidharan S, Lee C, Lee J, Ko H, editors. KLog-Home: A holistic approach of in-situ monitoring in elderly-care home. Proceedings - 22nd IEEE International Conference on Computational Science and Engineering and 17th IEEE International Conference on Embedded and Ubiquitous Computing, CSE/EUC 2019; 2019.

100. Lanza F, Seidita V, Chella A. Agents and robots for collaborating and supporting physicians in healthcare scenarios. J Biomed Inform. 2020;108:103483.

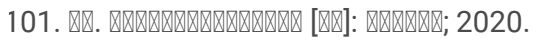

102. Chen IH, Chen $\mathrm{CH}$, Ting YC, Hung WL, Cheng BY. The Guardian Slippers: Designing an loT Device to Enhance Safety for the Elderly in the Nursing Home. Lecture Notes in Networks and Systems2021. p. 369-77.

103. Flores-Martin D, Rojo J, Moguel E, Berrocal J, Murillo JM. Smart Nursing Homes: Self-Management Architecture Based on loT and Machine Learning for Rural Areas. Wireless Communications and Mobile Computing. 2021;2021.

104. Chan WM, Woo J, Hui E, Hjelm NM. The role of telenursing in the provision of geriatric outreach services to residential homes in Hong Kong. Journal of telemedicine and telecare. 2001;7(1):38-46.

105. Pallawala PMDS, Lun KC. EMR-based TeleGeriatric system. Studies in health technology and informatics2001. p. 849-53.

106. Hui E, Woo J. Telehealth for older patients: the Hong Kong experience. Journal of telemedicine and telecare. 2002;8 Suppl 3:S3:39-41.

107. Weiner M, Schadow G, Lindbergh D, Warvel J, Abernathy G, Perkins SM, et al. Clinicians' and patients' experiences and satisfaction with unscheduled, nighttime, Internet-based video conferencing for assessing acute medical problems in a nursing facility. AMIA Annual Symposium proceedings AMIA Symposium. 2003:709-13.

108. Armer JM, Harris K, Dusold JM. Application of the Concerns-Based Adoption Model to the installation of telemedicine in a rural Missouri nursing home. Journal for nurses in staff development : JNSD : official journal of the National Nursing Staff Development Organization. 2004;20(1):429.

109. Savenstedt S, Zingmark K, Sandman PO. Being present in a distant room: aspects of teleconsultations with older people in a nursing home. Qualitative health research. 2004;14(8):1046-57.

110. Shulman B, Conn DK, Elford R. Geriatric telepsychiatry and telemedicine: A literature review. Canadian Journal of Geriatrics. 2006;9(4):139-46.

111. Cusack CM, Pan E, Hook JM, Vincent A, Kaelber DC, Middleton B. The value proposition in the widespread use of telehealth. Journal of telemedicine and telecare. 2008;14(4):167-8.

112. Janardhanan L, Leow YH, Chio MT, Kim Y, Soh CB. Experience with the implementation of a web-based teledermatology system in a nursing home in Singapore. Journal of telemedicine and telecare. 2008;14(8):404-9.

Page 12/36 
113. Biglan KM, Voss TS, Deuel LM, Miller D, Eason S, Fagnano M, et al. Telemedicine for the care of nursing home residents with Parkinson's disease. Movement disorders : official journal of the Movement Disorder Society. 2009;24(7):1073-6.

114. Qadri S, Wang J, Ruiz J, Roos B. Personal Digital Assistants as Point-of-Care Tools in Long-Term Care Facilities: A Pilot Study. Educational Gerontology. 2009;35(4):294-307.

115. Chang HL, Shaw MJ, Lai F, Ko WJ, Ho YL, Chen HS, et al. U-Health: An example of a high-quality individualized healthcare service. Personalized Medicine. 2010;7(6):677-87.

116. Wälivaara BM, Andersson S, Axelsson K. General practitioners' reasoning about using mobile distance-spanning technology in home care and in nursing home care. Scandinavian journal of caring sciences. 2011;25(1):117-25.

117. Gray LC, Edirippulige S, Smith AC, Beattie E, Theodoros D, Russell T, et al. Telehealth for nursing homes: The utilization of specialist services for residential care. Journal of telemedicine and telecare. 2012;18(3):142-6.

118. Grabowski DC, O'Malley AJ. Use of telemedicine can reduce hospitalizations of nursing home residents and generate savings for medicare. Health affairs (Project Hope). 2014;33(2):244-50.

119. Doumbouya MB, Kamsu-Foguem B, Kenfack H, Foguem C. Combining conceptual graphs and argumentation for aiding in the teleexpertise. Computers in Biology and Medicine. 2015;63:157-68.

120. Huang F, Chang P, Hou IC, Tu MH, Lan CF. Use of a mobile device by nursing home residents for long-term care comprehensive geriatric selfassessment: A feasibility study. CIN - Computers Informatics Nursing. 2015;33(1):28-36.

121. Toh HJ, Chia J, Koh E, Lam K, Magpantay GC, De Leon CM, et al., editors. User perceptions of the telemedicine programme in nursing homes the Singapore perspective. ICT4AgeingWell 2015 - Proceedings of the 1st International Conference on Information and Communication Technologies for Ageing Well and e-Health; 2015.

122. Toh HJ, Chia J, Koh E, Lam K, Magpantay GC, De Leon CM, et al. Increased engagement in telegeriatrics reduces unnecessary hospital admissions of nursing home residents. Communications in Computer and Information Science2015. p. 81-90.

123. De Luca R, Bramanti A, De Cola MC, Trifiletti A, Tomasello P, Torrisi M, et al. Tele-health-care in the elderly living in nursing home: the first Sicilian multimodal approach. Aging clinical and experimental research. 2016;28(4):753-9.

124. Driessen J, Bonhomme A, Chang W, Nace DA, Kavalieratos D, Perera S, et al. Nursing Home Provider Perceptions of Telemedicine for Reducing Potentially Avoidable Hospitalizations. Journal of the American Medical Directors Association. 2016;17(6):519-24.

125. Gaglio G, Lewkowicz M, Tixier M, editors. "It is not because you have tools that you must use them" The difficult domestication of a telemedicine toolkit to manage emergencies in nursing homes. Proceedings of the International ACM SIGGROUP Conference on Supporting Group Work; 2016.

126. Gillespie SM, Shah MN, Wasserman EB, Wood NE, Wang H, Noyes K, et al. Reducing emergency department utilization through engagement in telemedicine by senior living communities. Telemedicine and e-Health. 2016;22(6):489-96.

127. Morley JE. Telemedicine: Coming to Nursing Homes in the Near Future. Journal of the American Medical Directors Association. 2016;17(1):1-3.

128. Schneider R, Dorsey ER, Biglan K. Telemedicine Care for Nursing Home Residents with Parkinsonism. Journal of the American Geriatrics Society. 2016;64(1):218-20.

129. Newbould L, Mountain G, Hawley M, Ariss S. Remote Health Care Provision in Care Homes. Studies in health technology and informatics. 2017;242:148-51.

130. Esteves M, Esteves M, Abelha A, Machado J, editors. A mobile health application to assist health professionals: A case study in a Portuguese nursing home. ICT4AWE 2019 - Proceedings of the 5th International Conference on Information and Communication Technologies for Ageing Well and e-Health; 2019.

131. Ozkaynak M, Reeder B, Drake C, Ferrarone P, Trautner B, Wald H, et al. Characterizing Workflow to Inform Clinical Decision Support Systems in Nursing Homes. The Gerontologist. 2019;59(6):1024-33.

132. Shafiee Hanjani L, Peel NM, Freeman CR, Gray LC. Using telehealth to enable collaboration of pharmacists and geriatricians in residential medication management reviews. International journal of clinical pharmacy. 2019;41(5):1256-61.

133. Alexander GL, Powell KR, Deroche CB. An evaluation of telehealth expansion in U.S. nursing homes. Journal of the American Medical Informatics Association. 2021;28(2):342-8.

134. Cormi C, Chrusciel J, Laplanche D, Dramé M, Sanchez S. Telemedicine in nursing homes during the COVID-19 outbreak: A star is born (again). Geriatrics and Gerontology International. 2020;20(6):646-7.

135. Okamoto L, Okamoto L, Uechi M, Blanchette P, von Preyss-Friedman S. Renaissance in the Nursing Home During the COVID-19 Pandemic: Telemedicine Blooms in a Time of Crisis. Journal of the American Medical Directors Association. 2021;22(3):B16.

136. Daly JM, Jogerst G, Park JY, Kang YD, Bae T. A nursing home telehealth system: keeping residents connected. Journal of gerontological nursing. 2005;31(8):46-51.

137. Catic AG, Mattison ML, Bakaev I, Morgan M, Monti SM, Lipsitz L. ECHO-AGE: an innovative model of geriatric care for long-term care residents with dementia and behavioral issues. Journal of the American Medical Directors Association. 2014;15(12):938-42. 
138. Volicer L. Nursing home telepsychiatry. Journal of the American Medical Directors Association. 2015;16(1):7-8.

139. Gentry MT, Lapid MI, Rummans TA. Geriatric Telepsychiatry: Systematic Review and Policy Considerations. The American journal of geriatric psychiatry : official journal of the American Association for Geriatric Psychiatry. 2019;27(2):109-27.

140. Low JA, Toh HJ, Tan LLC, Chia JWK, Soek ATS. The Nuts and Bolts of Utilizing Telemedicine in Nursing Homes - The GeriCare@North Experience. Journal of the American Medical Directors Association. 2020;21(8):1073-8.

141. Zelickson BD. Teledermatology in the nursing home. Current problems in dermatology. 2003;32:167-71.

142. Lavanya J, Goh KW, Leow YH, Chio MT, Prabaharan K, Kim E, et al. Distributed personal health information management system for dermatology at the homes for senior citizens. Conference proceedings : Annual International Conference of the IEEE Engineering in Medicine and Biology Society IEEE Engineering in Medicine and Biology Society Annual Conference. 2006;2006:6312-5.

143. Vowden K, Vowden P. A pilot study on the potential of remote support to enhance wound care for nursing-home patients. Journal of wound care. 2013;22(9):481-8.

144. Ohligs M, Stocklassa S, Rossaint R, Czaplik M, Follmann A. Employment of Telemedicine in Nursing Homes: Clinical Requirement Analysis, System Development and First Test Results. Clinical interventions in aging. 2020;15:1427-37.

145. Novak L, Walker S, Fonda S, Schmidt V, Vigersky R. The impact of a video phone reminder system on glycemic control in older adults with type 2 diabetes mellitus (T2DM) in a retirement home. Diabetes. 2013;62:A217.

146. Crotty M, Killington M, van den Berg M, Morris C, Taylor A, Carati C. Telerehabilitation for older people using off-the-shelf applications: acceptability and feasibility. Journal of telemedicine and telecare. 2014;20(7):370-6.

147. Queyroux A, Saricassapian B, Herzog D, Muller K, Herafa I, Ducoux D, et al. Accuracy of Teledentistry for Diagnosing Dental Pathology Using Direct Examination as a Gold Standard: Results of the Tel-e-dent Study of Older Adults Living in Nursing Homes. Journal of the American Medical Directors Association. 2017;18(6):528-32.

148. Lai KY, Pathipati MP, Blumenkranz MS, Leung LS, Moshfeghi DM, Toy BC, et al. Assessment of Eye Disease and Visual Impairment in the Nursing Home Population Using Mobile Health Technology. Ophthalmic Surg Lasers Imaging Retina. 2020;51(5):262-70.

149. Loeb MB, Carusone SB, Marrie TJ, Brazil K, Krueger P, Lohfeld L, et al. Interobserver reliability of radiologists' interpretations of mobile chest radiographs for nursing home-acquired pneumonia. Journal of the American Medical Directors Association. 2006;7(7):416-9.

150. Eklund K, Klefsgard R, Ivarsson B, Geijer M. Positive experience of a mobile radiography service in nursing homes. Gerontology. 2012;58(2):10711.

151. Montalto M, Shay S, Le A. Evaluation of a mobile X-ray service for elderly residents of residential aged care facilities. Australian Health Review. 2015;39(5):517-21.

152. Dozet A, Ivarsson B, Eklund K, Klefsgard R, Geijer M. Radiography on wheels arrives to nursing homes - an economic assessment of a new health care technology in southern Sweden. Journal of evaluation in clinical practice. 2016;22(6):990-7.

153. Kjelle E, Lysdahl KB, Olerud HM, Myklebust AM. Managers' experience of success criteria and barriers to implementing mobile radiography services in nursing homes in Norway: a qualitative study. BMC health services research. 2018;18(1):301.

154. Kjelle E, Lysdahl KB. Mobile radiography services in nursing homes: a systematic review of residents' and societal outcomes. BMC health services research. 2017;17(1):231.

155. Savenstedt S, Bucht G, Norberg L, Sandman PO. Nurse-doctor interaction in teleconsultations between a hospital and a geriatric nursing home. Journal of telemedicine and telecare. 2002;8(1):11-8.

156. Handler SM, Boyce RD, Ligons FM, Perera S, Nace DA, Hochheiser H. Use and perceived benefits of mobile devices by physicians in preventing adverse drug events in the nursing home. Journal of the American Medical Directors Association. 2013;14(12):906-10.

157. Cherry BJ. Determining facilitators and barriers to adoption of electronic health records in long -term care facilities [D.N.Sc.]. Ann Arbor: The University of Tennessee Health Science Center; 2006.

158. Scott-Cawiezell J, Madsen RW, Pepper GA, Vogelsmeier A, Petroski G, Zellmer D. Medication safety teams' guided implementation of electronic medication administration records in five nursing homes. Joint Commission journal on quality and patient safety. 2009;35(1):29-35.

159. Alexander GL, Rantz M, Galambos C, Vogelsmeier A, Flesner M, Popejoy L, et al. Preparing Nursing Homes for the Future of Health Information Exchange. Applied clinical informatics. 2015;6(2):248-66.

160. Q

161. Celler BG, Basilakis J, Budge M, Lovel NH. A clinical monitoring and management system for residential aged care facilities. Conference proceedings : Annual International Conference of the IEEE Engineering in Medicine and Biology Society IEEE Engineering in Medicine and Biology Society Annual Conference. 2006;2006:3301-4.

162. Alexander GL. A descriptive analysis of a nursing home clinical information system with decision support. Perspectives in health information management. 2008;5:12.

163. Ohol RR. Web Based Nursing Home Information System: Needs, Benefits, and Success in Providing Efficient Care at Long Term Care Facilities [M.S.]. Ann Arbor: University of Missouri - Columbia; 2010.

Page 14/36 
164. Sax C, Lawrence E, editors. Point-of-treatment: Touchable e-nursing user interface for medical emergencies. 3rd International Conference on Mobile Ubiquitous Computing, Systems, Services, and Technologies, UBICOMM 2009; 2009.

165. Yu P, Hailey D, Li H. Caregivers' acceptance of electronic documentation in nursing homes. Journal of telemedicine and telecare. 2008;14(5):2615.

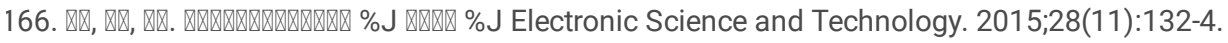

167. Byrne CM. Impact of prospective computerized clinical decision support information and targeted assistance on nursing home resident outcomes [Ph.D.]. Ann Arbor: State University of New York at Albany; 2005.

168. Matusitz J, Breen GM, Wan TT. The use of eHealth services in US nursing homes as an improvement of healthcare delivery to residents. Aging Health. 2013;9(1):25-33.

169. Ausserhofer D, Favez L, Simon M, Zúñiga F. Electronic Health Record Use in Swiss Nursing Homes and Its Association With Implicit Rationing of Nursing Care Documentation: Multicenter Cross-sectional Survey Study. JMIR Medical Informatics. 2021;9(3).

170. Kei Hong S, Ting CW, Chui PL, Teddy Tai-Ning L, Sau Chu C, Cheung YT. Medication Management Service for Old Age Homes in Hong Kong Using Information Technology, Automation Technology, and the Internet of Things: Pre-Post Interventional Study. JMIR Medical Informatics. $2021 ; 9(2)$

171. Lenderink BW, Egberts TC. Closing the loop of the medication use process using electronic medication administration registration. Pharmacy world \& science : PWS. 2004;26(4):185-90.

172. Alexander GL. Human factors, automation, and alerting mechanisms in nursing home electronic health records [Ph.D.]. Ann Arbor: University of Missouri - Columbia; 2005.

173. Alexander GL, Rantz M, Flesner M, Diekemper M, Siem C. Clinical information systems in nursing homes: an evaluation of initial implementation strategies. CIN: Computers, Informatics, Nursing. 2007;25(4):189-97.

174. Breen GM, Zhang NJ. Introducing ehealth to nursing homes: theoretical analysis of improving resident care. Journal of medical systems. 2008;32(2):187-92.

175. Wang Y. “"

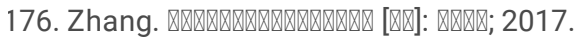

177. Roh EH, Park SC. A study on the quality of life improvement in fixed loT environments: Utilizing active aging biomarkers and big data. Quality Innovation Prosperity. 2017;21(2):52-70.

178. Kokubo R, Kamiya Y, editors. A novel period estimation method for periodic signals suitable for vital sensing. ACM International Conference Proceeding Series; 2019.

179. González I, Navarro FJ, Fontecha J, Cabañero-Gómez L, Hervás R. An Internet of Things infrastructure for gait characterization in assisted living environments and its application in the discovery of associations between frailty and cognition. International Journal of Distributed Sensor Networks. 2019;15(10).

180. Ambagtsheer RC, Shafiabady N, Dent E, Seiboth C, Beilby J. The application of artificial intelligence (AI) techniques to identify frailty within a residential aged care administrative data set. International journal of medical informatics. 2020;136.

181. Hsu WC, Kuo CW, Chang WW, Chang JJ, Hou YT, Lan YC, et al., editors. A WSN smart medication system. Procedia Engineering; 2010.

182. Chang WW, Sung TJ, Huang HW, Hsu WC, Kuo CW, Chang JJ, et al. A smart medication system using wireless sensor network technologies. Sensors and Actuators, A: Physical. 2011;172(1):315-21.

183. Tsai HL, Tseng CH, Wang LC, Juang FS, editors. Bidirectional smart pill box monitored through internet and receiving reminding message from remote relatives. 2017 IEEE International Conference on Consumer Electronics - Taiwan, ICCE-TW 2017; 2017.

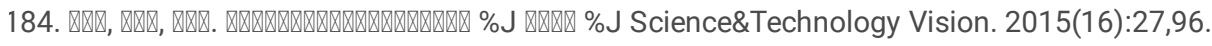

185. Sauser B, Verma D, Ramirez-Marquez J, Gove R, editors. From TRL to SRL: The concept of systems readiness levels. Conference on Systems Engineering Research, Los Angeles, CA; 2006.

186. Rabinowitz T, Murphy KM, Amour JL, Ricci MA, Caputo MP, Newhouse PA. Benefits of a telepsychiatry consultation service for rural nursing home residents. Telemedicine journal and e-health : the official journal of the American Telemedicine Association. 2010;16(1):34-40.

187. Dozet A, Ivarsson B, Eklund K, Klefsgård R, Geijer M. Radiography on wheels arrives to nursing homes - an economic assessment of a new health care technology in southern Sweden. Journal of evaluation in clinical practice. 2016;22(6):990-7.

188. Chang JY, Chen LK, Chang CC. Perspectives and expectations for telemedicine opportunities from families of nursing home residents and caregivers in nursing homes. International journal of medical informatics. 2009;78(7):494-502.

189. Berker T, Hartmann M, Punie Y. Domestication of media and technology: McGraw-Hill Education (UK); 2005.

190. Delmastro F, Dolciotti C, La Rosa D, Di Martino F, Magrini M, Coscetti S, et al. Experimenting mobile and e-health services with frail MCl older people. Information (Switzerland). 2019;10(8).

191. Fraile JA, Bajo J, Corchado JM, Abraham A. Applying wearable solutions in dependent environments. IEEE Trans Inf Technol Biomed. 2010;14(6):1459-67 
192. Tsertsidis A, Kolkowska E, Hedström K. Factors influencing seniors' acceptance of technology for ageing in place in the post-implementation stage: A literature review. International journal of medical informatics. 2019;129:324-33.

193. Pal D, Triyason T, Funikul S, editors. Smart Homes and Quality of Life for the Elderly: A Systematic Review. 2017 IEEE International Symposium on Multimedia (ISM); 2017 11-13 Dec. 2017.

194. Marikyan D, Papagiannidis S, Alamanos E. A systematic review of the smart home literature: A user perspective. Technological Forecasting and Social Change. 2019;138:139-54.

195. Tun SYY, Madanian S, Mirza F. Internet of things (loT) applications for elderly care: a reflective review. Aging clinical and experimental research. 2020:1-13.

196. Botezat D, Oprea L, lliescu R. Integrating medical services: a solution for an efficient and equitable health system. Revista Romana de Bioetica. 2013;11(4):93-107.

\section{Tables}

Table 1: The Codes of Defining the Concepts and Criteria of a Smart Nursing Home

Table 1a: Concept of Smart Nursing Homes 


\begin{tabular}{|c|c|c|c|}
\hline Authors and year & Codes & Description & Themes \\
\hline $\begin{array}{l}\text { Baidu, 2018; Ce.cn, 2019; Chen \& Li, 2012; } \\
\text { Gamberini et al., 2018; Huang et al., 2019; } \\
\text { Korte; Lee et al., 2018; Mahieu et al., 2019; } \\
\text { MCA, 2014; Roh \& Park, 2017; Shenghuo, } \\
\text { 2020; Tang et al., 2019; Wang, 2014; Wang, } \\
\text { 2020; Xie, 2017; Xiexiebang, 2019; Xu \& Tuo, } \\
\text { 2019 }\end{array}$ & $\mathrm{loT} \mathrm{T}^{\mathrm{a}}$ & \multirow[t]{7}{*}{$\begin{array}{l}\text { The concept of smartness in nursing home settings is using } \\
\text { a new generation of information technologies such as the } \\
\text { internet of things (loT), computing technologies, cloud } \\
\text { computing, big data and Al, information management } \\
\text { system and digital health, to transform traditional nursing } \\
\text { care in an all-round way, making healthcare more efficient, } \\
\text { more effective, and more personalised. }\end{array}$} & \multirow[t]{7}{*}{$\begin{array}{l}\text { Application } \\
\text { of smart } \\
\text { technologies } \\
\text { (Smartness) }\end{array}$} \\
\hline Cui et al., 2020; Korte; SheCuiTong; Telpo & $\begin{array}{l}\text { Computing } \\
\text { technologies }\end{array}$ & & \\
\hline Ce.cn, 2019 & $\begin{array}{l}\text { Cloud } \\
\text { computing }\end{array}$ & & \\
\hline $\begin{array}{l}\text { Cui et al., 2020; Mahieu et al., 2019; MHURD; } \\
\text { Telpo; Xu \& Tuo, } 2019\end{array}$ & $\begin{array}{l}\text { Big data and } \\
\mathrm{Al}^{\mathrm{b}}\end{array}$ & & \\
\hline Baidu, 2018; Liuye; MHURD; Morley, 2012 & $\begin{array}{l}\text { Information } \\
\text { management } \\
\text { system (IMS) }\end{array}$ & & \\
\hline $\begin{array}{l}\text { BOE Technology Group Co., 2018; MHURD; } \\
\text { Morley, 2012; Shenghuo, 2020; Telpo }\end{array}$ & Digital health & & \\
\hline $\begin{array}{l}\text { Shenghuo, 2020; Siciliano \& Khatib, 2016; } \\
\text { Sun et al., } 2015\end{array}$ & $\begin{array}{l}\text { Assistive } \\
\text { devices }\end{array}$ & & \\
\hline $\begin{array}{l}\text { Cui et al., 2020; Deng, 2019; MCA, 2014; Tang } \\
\text { et al., } 2019\end{array}$ & $\begin{array}{l}\text { Intelligent } \\
\text { nursing }\end{array}$ & \multirow{4}{*}{$\begin{array}{l}\text { A nursing home offers technology-assisted nursing care for } \\
\text { the people who require a lot of assistance with activities of } \\
\text { daily living to improve their quality of life in relation to their } \\
\text { goals, expectations, standards and concerns. }\end{array}$} & \multirow{4}{*}{$\begin{array}{l}\text { Technology- } \\
\text { assisted } \\
\text { nursing care }\end{array}$} \\
\hline Korte; Lee et al., 2018; Xie, 2017 & $\begin{array}{l}\text { Automated } \\
\text { tracking, } \\
\text { monitoring and } \\
\text { alerts }\end{array}$ & & \\
\hline Huang, 2019; Korte; Wang, 2014 & $\begin{array}{l}\text { Improving } \\
\text { quality of life }\end{array}$ & & \\
\hline $\begin{array}{l}\text { Baidu, 2018; Cui et al., 2020; MHURD; Tang et } \\
\text { al., } 2019\end{array}$ & $\begin{array}{l}\text { Meeting older } \\
\text { adults and } \\
\text { users' } \\
\text { satisfaction }\end{array}$ & & \\
\hline Cui et al., 2020; Korte; Morley, 2012 & $\begin{array}{l}\text { Similar to smart } \\
\text { home }\end{array}$ & \multirow{4}{*}{$\begin{array}{l}\text { The concept belongs to smart homes with specific users. It } \\
\text { performs as a home-based care with the functions of both } \\
\text { home and hospital to guarantee a better environment for } \\
\text { older adults. }\end{array}$} & \multirow{4}{*}{$\begin{array}{l}\text { Combination } \\
\text { of smart } \\
\text { home and } \\
\text { hospital } \\
\text { model }\end{array}$} \\
\hline Cui et al., 2020; Korte & $\begin{array}{l}\text { Home and } \\
\text { hospital models }\end{array}$ & & \\
\hline Gamberini et al., 2018 & $\begin{array}{l}\text { More } \\
\text { comfortable } \\
\text { and safe } \\
\text { environments }\end{array}$ & & \\
\hline Cui et al., 2020; Siciliano \& Khatib, 2016 & $\begin{array}{l}\text { Special users- } \\
\text { older adults } \\
\text { and caregivers }\end{array}$ & & \\
\hline
\end{tabular}

Table 1b: Criteria of Smart Nursing Homes 


\begin{tabular}{|c|c|c|c|}
\hline Authors and year & Codes & Description & Themes \\
\hline $\begin{array}{l}\text { Baidu, 2018; Huang et al., 2019; } \\
\text { Korte; Matusitz et al., 2013; } \\
\text { MHURD; Tang et al., 2019 }\end{array}$ & $\begin{array}{l}\text { Provide/improve } \\
\text { quality of care }\end{array}$ & \multirow[t]{5}{*}{$\begin{array}{l}\text { The quality of care is the extent to which health care services provided to } \\
\text { individuals and patient populations improve desired health outcomes. In order } \\
\text { to achieve this, health care must be safe, effective, timely, efficient, equitable } \\
\text { and people-centered. (WHO). }\end{array}$} & \multirow[t]{5}{*}{$\begin{array}{l}\text { Quality } \\
\text { of care }\end{array}$} \\
\hline $\begin{array}{l}\text { Huang et al., 2019; MHURD; } \\
\text { Siciliano \& Khatib, 2016; Wang, } \\
\text { 2020; Xiexiebang, 2019 }\end{array}$ & Safe & & \\
\hline $\begin{array}{l}\text { Baidu, 2018; Betgé-Brezetz et } \\
\text { al., 2009; Cui et al., 2020; } \\
\text { MHURD; Shenghuo, 2020; Tang } \\
\text { et al., } 2019\end{array}$ & Effective & & \\
\hline $\begin{array}{l}\text { Baidu, 2018; Cui et al., 2020; } \\
\text { SheCuiTong; Siciliano \& Khatib, } \\
\text { 2016; Tang et al., 2019; } \\
\text { Xiexiebang, } 2019\end{array}$ & Efficient & & \\
\hline $\begin{array}{l}\text { Cui et al., 2020; Huang et al., } \\
\text { 2019; Korte; MHURD; Telpo; } \\
\text { Wang, } 2014\end{array}$ & $\begin{array}{l}\text { People-centered } \\
\text { (PC) }\end{array}$ & & \\
\hline
\end{tabular}

${ }^{\text {a }}$ IoT=Internet of things

${ }^{\mathrm{b}} \mathrm{Al}=$ Artificial intelligence

Table 2: The Codes of Smart Technologies 


\begin{tabular}{|c|c|c|c|c|c|c|c|c|}
\hline No. & $\begin{array}{l}\text { Authors and } \\
\text { year }\end{array}$ & Country & $\begin{array}{l}\text { Type of } \\
\text { Publication }\end{array}$ & Study design & Application & $\begin{array}{l}\text { Technologies } \\
\text { related to } \\
\text { 'smartness' }\end{array}$ & Direct User & $\begin{array}{l}\text { Function of } \\
\text { Technology }\end{array}$ \\
\hline 1 & $\begin{array}{l}\text { Suzuki et al., } \\
2006\end{array}$ & Japan & $\begin{array}{l}\text { Journal } \\
\text { article }\end{array}$ & $\begin{array}{l}\text { System } \\
\text { design }\end{array}$ & $\begin{array}{l}\text { Monitoring abnormal } \\
\text { events (only } \\
\text { location) }\end{array}$ & IoT & Residents $^{a}$ & \multirow{25}{*}{$\begin{array}{l}\text { Monitoring } \\
\text { and } \\
\text { notification } \\
\text { of abnormal } \\
\text { events }\end{array}$} \\
\hline 2 & $\begin{array}{l}\text { Fischer et al., } \\
2008\end{array}$ & Australia & $\begin{array}{l}\text { Conference } \\
\text { paper }\end{array}$ & $\begin{array}{l}\text { System } \\
\text { design }\end{array}$ & $\begin{array}{l}\text { Monitoring abnormal } \\
\text { events }\end{array}$ & IoT & Residents & \\
\hline 3 & $\begin{array}{l}\text { Lin et al., } \\
2008\end{array}$ & $\begin{array}{l}\text { Taiwan, } \\
\text { China }\end{array}$ & $\begin{array}{l}\text { Conference } \\
\text { paper }\end{array}$ & $\begin{array}{l}\text { System } \\
\text { design }\end{array}$ & $\begin{array}{l}\text { Monitoring abnormal } \\
\text { events }\end{array}$ & IoT & Residents & \\
\hline 4 & $\begin{array}{l}\text { Betgé- } \\
\text { Brezetz et al., } \\
2009\end{array}$ & USA & $\begin{array}{l}\text { Conference } \\
\text { paper }\end{array}$ & $\begin{array}{l}\text { System } \\
\text { design }\end{array}$ & $\begin{array}{l}\text { Notification for } \\
\text { specific events }\end{array}$ & $\begin{array}{l}\text { Computing } \\
\text { technologies }\end{array}$ & Residents & \\
\hline \multirow[t]{2}{*}{5} & $\begin{array}{l}\text { Biswas et al., } \\
2009\end{array}$ & Singapore & Book & $\begin{array}{l}\text { System } \\
\text { design }\end{array}$ & $\begin{array}{l}\text { Monitoring abnormal } \\
\text { events }\end{array}$ & IoT & Residents & \\
\hline & & & & & $\begin{array}{l}\text { (Sleeping } \\
\text { monitoring) }\end{array}$ & & & \\
\hline 6 & $\begin{array}{l}\text { Hu et al., } \\
2009\end{array}$ & USA & $\begin{array}{l}\text { Journal } \\
\text { article }\end{array}$ & $\begin{array}{l}\text { System } \\
\text { design }\end{array}$ & $\begin{array}{l}\text { Monitoring abnormal } \\
\text { events }\end{array}$ & IoT & $\mathrm{NH}^{\mathrm{b}}$ staffs & \\
\hline 7 & $\begin{array}{l}\text { Fraile et al., } \\
2010\end{array}$ & Spain & $\begin{array}{l}\text { Conference } \\
\text { paper }\end{array}$ & $\begin{array}{l}\text { System } \\
\text { design }\end{array}$ & $\begin{array}{l}\text { Monitoring abnormal } \\
\text { events }\end{array}$ & IoT & Residents & \\
\hline 8 & $\begin{array}{l}\text { Pallikonda } \\
\text { Rajasekaran } \\
\text { et al., } 2010\end{array}$ & India & $\begin{array}{l}\text { Journal } \\
\text { article }\end{array}$ & $\begin{array}{l}\text { System } \\
\text { design }\end{array}$ & $\begin{array}{l}\text { Monitoring abnormal } \\
\text { events }\end{array}$ & IoT & Residents & \\
\hline 9 & $\begin{array}{l}\text { Gower et al., } \\
2011\end{array}$ & Italy & $\begin{array}{l}\text { Conference } \\
\text { paper }\end{array}$ & $\begin{array}{l}\text { System } \\
\text { design }\end{array}$ & $\begin{array}{l}\text { Monitoring abnormal } \\
\text { events }\end{array}$ & IoT & Residents & \\
\hline 10 & $\begin{array}{l}\text { Lee et al., } \\
2011\end{array}$ & $\begin{array}{l}\text { South } \\
\text { Korea }\end{array}$ & $\begin{array}{l}\text { Journal } \\
\text { article }\end{array}$ & $\begin{array}{l}\text { System } \\
\text { design }\end{array}$ & $\begin{array}{l}\text { Monitoring abnormal } \\
\text { events }\end{array}$ & IoT & Residents & \\
\hline 11 & Sun, 2011 & China & Book & $\begin{array}{l}\text { System } \\
\text { design }\end{array}$ & $\begin{array}{l}\text { Monitoring abnormal } \\
\text { events }\end{array}$ & IoT & Residents & \\
\hline 12 & $\begin{array}{l}\text { Wu \& Huang, } \\
2011\end{array}$ & $\begin{array}{l}\text { Taiwan, } \\
\text { China }\end{array}$ & $\begin{array}{l}\text { Conference } \\
\text { paper }\end{array}$ & $\begin{array}{l}\text { System } \\
\text { design }\end{array}$ & $\begin{array}{l}\text { Monitoring abnormal } \\
\text { events }\end{array}$ & IoT & Residents & \\
\hline 13 & $\begin{array}{l}\text { Back et al., } \\
2012\end{array}$ & Finland & $\begin{array}{l}\text { Journal } \\
\text { article }\end{array}$ & $\begin{array}{l}\text { System } \\
\text { design }\end{array}$ & $\begin{array}{l}\text { Monitoring abnormal } \\
\text { events }\end{array}$ & IoT & Residents & \\
\hline 14 & $\begin{array}{l}\text { Chang et al., } \\
2012\end{array}$ & $\begin{array}{l}\text { Taiwan, } \\
\text { China }\end{array}$ & $\begin{array}{l}\text { Journal } \\
\text { article }\end{array}$ & $\begin{array}{l}\text { System } \\
\text { design }\end{array}$ & $\begin{array}{l}\text { Monitoring abnormal } \\
\text { events }\end{array}$ & IoT & Residents & \\
\hline 15 & $\begin{array}{l}\text { Chen \& Li, } \\
2012\end{array}$ & China & Thesis & $\begin{array}{l}\text { System } \\
\text { design }\end{array}$ & $\begin{array}{l}\text { Monitoring abnormal } \\
\text { events }\end{array}$ & IoT & Residents & \\
\hline \multirow[t]{2}{*}{16} & $\begin{array}{l}\text { Nijhof et al., } \\
2012\end{array}$ & Netherlands & $\begin{array}{l}\text { Journal } \\
\text { article }\end{array}$ & $\begin{array}{l}\text { Mixed } \\
\text { methods }\end{array}$ & $\begin{array}{l}\text { Monitoring abnormal } \\
\text { events }\end{array}$ & IoT & Residents & \\
\hline & & & & & $\begin{array}{l}\text { (Sleep/wake rhythm } \\
\text { monitoring) }\end{array}$ & & & \\
\hline 17 & $\begin{array}{l}\text { Ghorbel et } \\
\text { al., } 2013\end{array}$ & France & $\begin{array}{l}\text { Journal } \\
\text { article }\end{array}$ & $\begin{array}{l}\text { System } \\
\text { design }\end{array}$ & $\begin{array}{l}\text { Notification for } \\
\text { specific events }\end{array}$ & $\begin{array}{l}\text { Computing } \\
\text { technologies }\end{array}$ & Residents & \\
\hline 18 & $\begin{array}{l}\text { Huang et al., } \\
2013\end{array}$ & $\begin{array}{l}\text { Taiwan, } \\
\text { China }\end{array}$ & $\begin{array}{l}\text { Conference } \\
\text { paper }\end{array}$ & $\begin{array}{l}\text { System } \\
\text { design }\end{array}$ & $\begin{array}{l}\text { Monitoring abnormal } \\
\text { events }\end{array}$ & IoT & Residents & \\
\hline 19 & $\begin{array}{l}\text { Matsui et al., } \\
2013\end{array}$ & USA & $\begin{array}{l}\text { Journal } \\
\text { article }\end{array}$ & $\begin{array}{l}\text { System } \\
\text { design }\end{array}$ & $\begin{array}{l}\text { Monitoring abnormal } \\
\text { events }\end{array}$ & $\begin{array}{l}\text { Computing } \\
\text { technologies }\end{array}$ & Residents & \\
\hline 20 & $\begin{array}{l}\text { Neuhaeuser } \\
\text { \& D'Angelo, } \\
2013\end{array}$ & Germany & $\begin{array}{l}\text { Conference } \\
\text { paper }\end{array}$ & $\begin{array}{l}\text { System } \\
\text { design }\end{array}$ & $\begin{array}{l}\text { Monitoring abnormal } \\
\text { events }\end{array}$ & IoT & Residents & \\
\hline 21 & Pan, 2013 & China & Thesis & $\begin{array}{l}\text { System } \\
\text { design }\end{array}$ & $\begin{array}{l}\text { Monitoring abnormal } \\
\text { events }\end{array}$ & IoT & Residents & \\
\hline 22 & $\begin{array}{l}\text { Tseng et al., } \\
2013\end{array}$ & USA & $\begin{array}{l}\text { Journal } \\
\text { article }\end{array}$ & $\begin{array}{l}\text { System } \\
\text { design }\end{array}$ & $\begin{array}{l}\text { Monitoring abnormal } \\
\text { events }\end{array}$ & IoT & Residents & \\
\hline 23 & $\begin{array}{l}\text { Abbate et al., } \\
2014\end{array}$ & Italy & $\begin{array}{l}\text { Journal } \\
\text { article }\end{array}$ & Experimental $^{\mathrm{C}}$ & Fall detection & IoT & Residents & \\
\hline
\end{tabular}




\begin{tabular}{|c|c|c|c|c|c|c|c|}
\hline 24 & $\begin{array}{l}\text { Chu et al., } \\
2014\end{array}$ & China & $\begin{array}{l}\text { Journal } \\
\text { article }\end{array}$ & $\begin{array}{l}\text { System } \\
\text { design }\end{array}$ & $\begin{array}{l}\text { Monitoring abnormal } \\
\text { events }\end{array}$ & loT & Residents \\
\hline \multirow[t]{2}{*}{25} & $\begin{array}{l}\text { Liu \& Hsu, } \\
2014\end{array}$ & $\begin{array}{l}\text { Taiwan, } \\
\text { China }\end{array}$ & $\begin{array}{l}\text { Journal } \\
\text { article }\end{array}$ & $\begin{array}{l}\text { System } \\
\text { design }\end{array}$ & $\begin{array}{l}\text { Monitoring abnormal } \\
\text { events }\end{array}$ & IoT & Residents \\
\hline & & & & & (Smart mattress) & & \\
\hline 26 & Wang, 2014 & China & Thesis & $\begin{array}{l}\text { System } \\
\text { design }\end{array}$ & $\begin{array}{l}\text { Monitoring abnormal } \\
\text { events }\end{array}$ & loT & Residents \\
\hline \multirow[t]{2}{*}{27} & $\begin{array}{l}\text { Zhu et al., } \\
2014\end{array}$ & Japan & $\begin{array}{l}\text { Conference } \\
\text { paper }\end{array}$ & $\begin{array}{l}\text { System } \\
\text { design }\end{array}$ & $\begin{array}{l}\text { Monitoring abnormal } \\
\text { events }\end{array}$ & loT & Residents \\
\hline & & & & & (Sleep monitoring) & & \\
\hline 28 & $\begin{array}{l}\text { Andò et al., } \\
2015\end{array}$ & Italy & $\begin{array}{l}\text { Conference } \\
\text { paper }\end{array}$ & $\begin{array}{l}\text { System } \\
\text { design }\end{array}$ & $\begin{array}{l}\text { Monitoring abnormal } \\
\text { events }\end{array}$ & loT & Residents \\
\hline 29 & $\begin{array}{l}\text { Carvalho et } \\
\text { al., } 2015\end{array}$ & France & $\begin{array}{l}\text { Conference } \\
\text { paper }\end{array}$ & $\begin{array}{l}\text { System } \\
\text { design }\end{array}$ & $\begin{array}{l}\text { Monitoring abnormal } \\
\text { events }\end{array}$ & loT & Residents \\
\hline 30 & $\begin{array}{l}\text { Yu et al., } \\
2015\end{array}$ & UK & $\begin{array}{l}\text { Conference } \\
\text { paper }\end{array}$ & $\begin{array}{l}\text { System } \\
\text { design }\end{array}$ & $\begin{array}{l}\text { Monitoring abnormal } \\
\text { events }\end{array}$ & IoT & Residents \\
\hline 31 & $\begin{array}{l}\text { Danielsen, } \\
2016\end{array}$ & Norway & $\begin{array}{l}\text { Journal } \\
\text { article }\end{array}$ & $\begin{array}{l}\text { System } \\
\text { design }\end{array}$ & $\begin{array}{l}\text { Monitoring abnormal } \\
\text { events }\end{array}$ & loT & Residents \\
\hline 32 & $\begin{array}{l}\text { Dias et al., } \\
2016\end{array}$ & Brazil & $\begin{array}{l}\text { Conference } \\
\text { paper }\end{array}$ & $\begin{array}{l}\text { System } \\
\text { design }\end{array}$ & Fall detection & loT & Residents \\
\hline 33 & $\begin{array}{l}\text { Lopez- } \\
\text { Samaniego \& } \\
\text { Garcia- } \\
\text { Zapirain, } \\
2016\end{array}$ & Spain & $\begin{array}{l}\text { Journal } \\
\text { article }\end{array}$ & $\begin{array}{l}\text { System } \\
\text { design }\end{array}$ & $\begin{array}{l}\text { Monitoring abnormal } \\
\text { events }\end{array}$ & loT & Residents \\
\hline 34 & $\begin{array}{l}\text { Ansefine et } \\
\text { al., } 2017\end{array}$ & Indonesia & $\begin{array}{l}\text { Conference } \\
\text { paper }\end{array}$ & $\begin{array}{l}\text { System } \\
\text { design }\end{array}$ & $\begin{array}{l}\text { Monitoring abnormal } \\
\text { events }\end{array}$ & loT & Residents \\
\hline 35 & Jiang, 2017 & China & Thesis & $\begin{array}{l}\text { System } \\
\text { design }\end{array}$ & $\begin{array}{l}\text { Monitoring abnormal } \\
\text { events }\end{array}$ & loT & Residents \\
\hline 36 & $\begin{array}{l}\text { Mendes et } \\
\text { al., } 2017\end{array}$ & Portugal & $\begin{array}{l}\text { Conference } \\
\text { paper }\end{array}$ & $\begin{array}{l}\text { System } \\
\text { design }\end{array}$ & $\begin{array}{l}\text { Monitoring abnormal } \\
\text { events }\end{array}$ & $\begin{array}{l}\text { Big data and } \\
\text { Al }\end{array}$ & Residents \\
\hline 37 & $\begin{array}{l}\text { Mendoza et } \\
\text { al., } 2017\end{array}$ & Philippines & $\begin{array}{l}\text { Conference } \\
\text { paper }\end{array}$ & $\begin{array}{l}\text { System } \\
\text { design }\end{array}$ & $\begin{array}{l}\text { Monitoring abnormal } \\
\text { events }\end{array}$ & loT & Residents \\
\hline \multirow[t]{2}{*}{38} & $\begin{array}{l}\text { Montanini et } \\
\text { al., } 2017\end{array}$ & Italy & $\begin{array}{l}\text { Conference } \\
\text { paper }\end{array}$ & $\begin{array}{l}\text { System } \\
\text { design }\end{array}$ & $\begin{array}{l}\text { Monitoring abnormal } \\
\text { events }\end{array}$ & loT & Residents \\
\hline & & & & & $\begin{array}{l}\text { (Night monitoring of } \\
\text { patients with } \\
\text { dementia) }\end{array}$ & & \\
\hline 39 & $\begin{array}{l}\text { Saod et al., } \\
2017\end{array}$ & Malaysia & $\begin{array}{l}\text { Conference } \\
\text { paper }\end{array}$ & $\begin{array}{l}\text { System } \\
\text { design }\end{array}$ & $\begin{array}{l}\text { Monitoring abnormal } \\
\text { events }\end{array}$ & loT & Residents \\
\hline 40 & $\begin{array}{l}\text { Singh et al., } \\
2017\end{array}$ & Austria & $\begin{array}{l}\text { Conference } \\
\text { paper }\end{array}$ & Qualitative & $\begin{array}{l}\text { Monitoring abnormal } \\
\text { events }\end{array}$ & loT & Residents \\
\hline 41 & $\begin{array}{l}\text { Wu et al., } \\
2017\end{array}$ & China & $\begin{array}{l}\text { Conference } \\
\text { paper }\end{array}$ & $\begin{array}{l}\text { System } \\
\text { design }\end{array}$ & $\begin{array}{l}\text { Monitoring abnormal } \\
\text { events }\end{array}$ & $\begin{array}{l}\text { Computing } \\
\text { technologies }\end{array}$ & Residents \\
\hline 42 & Xie, 2017 & China & Thesis & $\begin{array}{l}\text { System } \\
\text { design }\end{array}$ & $\begin{array}{l}\text { Monitoring abnormal } \\
\text { events }\end{array}$ & $\begin{array}{l}\text { Big data and } \\
\text { Al }\end{array}$ & Residents \\
\hline \multirow[t]{2}{*}{43} & $\begin{array}{l}\text { Bleda et al., } \\
2018\end{array}$ & Spain & $\begin{array}{l}\text { Conference } \\
\text { paper }\end{array}$ & $\begin{array}{l}\text { System } \\
\text { design }\end{array}$ & $\begin{array}{l}\text { Monitoring abnormal } \\
\text { events }\end{array}$ & loT & Residents \\
\hline & & & & & (Smart mattress) & & \\
\hline 44 & $\begin{array}{l}\text { Donnelly et } \\
\text { al., } 2018\end{array}$ & Ireland & $\begin{array}{l}\text { Journal } \\
\text { article }\end{array}$ & Qualitative & Fall detection & loT & Residents \\
\hline 45 & $\begin{array}{l}\text { Gamberini et } \\
\text { al., } 2018\end{array}$ & Italy & Book & $\begin{array}{l}\text { Non-research } \\
\text { article }^{d}\end{array}$ & $\begin{array}{l}\text { Monitoring abnormal } \\
\text { events }\end{array}$ & loT & Residents \\
\hline 46 & $\begin{array}{l}\text { Lee et al., } \\
2018\end{array}$ & $\begin{array}{l}\text { South } \\
\text { Korea }\end{array}$ & $\begin{array}{l}\text { Conference } \\
\text { paper }\end{array}$ & $\begin{array}{l}\text { System } \\
\text { design }\end{array}$ & $\begin{array}{l}\text { Monitoring abnormal } \\
\text { events }\end{array}$ & loT & Residents \\
\hline 47 & Mahfuz et & Canada & Conference & System & Fall detection & loT & Residents \\
\hline
\end{tabular}

Page 20/36 


\begin{tabular}{|c|c|c|c|c|c|c|c|}
\hline \multicolumn{3}{|c|}{ al., 2018} & \multirow{2}{*}{$\begin{array}{l}\text { paper } \\
\text { Conference } \\
\text { paper }\end{array}$} & \multicolumn{4}{|l|}{ design } \\
\hline 48 & $\begin{array}{l}\text { Morita et al., } \\
2018\end{array}$ & Japan & & $\begin{array}{l}\text { System } \\
\text { design }\end{array}$ & $\begin{array}{l}\text { Monitoring abnormal } \\
\text { events }\end{array}$ & $\begin{array}{l}\text { Big data and } \\
\text { Al }\end{array}$ & Residents \\
\hline 49 & $\begin{array}{l}\text { Wu et al., } \\
2018\end{array}$ & China & $\begin{array}{l}\text { Journal } \\
\text { article }\end{array}$ & $\begin{array}{l}\text { System } \\
\text { design }\end{array}$ & $\begin{array}{l}\text { Monitoring abnormal } \\
\text { events }\end{array}$ & loT & Residents \\
\hline 50 & $\begin{array}{l}\text { Borelli et al., } \\
2019\end{array}$ & Italy & $\begin{array}{l}\text { Journal } \\
\text { article }\end{array}$ & $\begin{array}{l}\text { System } \\
\text { design }\end{array}$ & $\begin{array}{l}\text { Monitoring abnormal } \\
\text { events }\end{array}$ & loT & Residents \\
\hline 51 & $\begin{array}{l}\text { Cai \& Wang, } \\
2019\end{array}$ & China & $\begin{array}{l}\text { Journal } \\
\text { article }\end{array}$ & $\begin{array}{l}\text { System } \\
\text { design }\end{array}$ & Fall detection & loT & Residents \\
\hline 52 & $\begin{array}{l}\text { Delmastro et } \\
\text { al., } 2019\end{array}$ & Italy & $\begin{array}{l}\text { Journal } \\
\text { article }\end{array}$ & Experimental & $\begin{array}{l}\text { Monitoring abnormal } \\
\text { events }\end{array}$ & $\begin{array}{l}\text { Cloud } \\
\text { computing }\end{array}$ & Residents \\
\hline 53 & Deng, 2019 & China & Thesis & $\begin{array}{l}\text { System } \\
\text { design }\end{array}$ & $\begin{array}{l}\text { Monitoring abnormal } \\
\text { events }\end{array}$ & IoT & Residents \\
\hline 54 & $\begin{array}{l}\text { Fong et al., } \\
2019\end{array}$ & USA & $\begin{array}{l}\text { Conference } \\
\text { paper }\end{array}$ & $\begin{array}{l}\text { System } \\
\text { design }\end{array}$ & $\begin{array}{l}\text { Monitoring abnormal } \\
\text { events }\end{array}$ & loT & Residents \\
\hline 55 & $\begin{array}{l}\text { Ghosh et al., } \\
2019\end{array}$ & India & $\begin{array}{l}\text { Conference } \\
\text { paper }\end{array}$ & $\begin{array}{l}\text { System } \\
\text { design }\end{array}$ & $\begin{array}{l}\text { Monitoring abnormal } \\
\text { events }\end{array}$ & $\begin{array}{l}\text { Big data and } \\
\text { Al }\end{array}$ & Residents \\
\hline 56 & Huang, 2019 & China & Thesis & $\begin{array}{l}\text { System } \\
\text { design }\end{array}$ & Fall detection & $\begin{array}{l}\text { Big data and } \\
\text { Al }\end{array}$ & Residents \\
\hline 57 & $\begin{array}{l}\text { Huang et al., } \\
2019\end{array}$ & $\begin{array}{l}\text { Taiwan, } \\
\text { China }\end{array}$ & $\begin{array}{l}\text { Conference } \\
\text { paper }\end{array}$ & $\begin{array}{l}\text { System } \\
\text { design }\end{array}$ & $\begin{array}{l}\text { Monitoring abnormal } \\
\text { events }\end{array}$ & loT & Residents \\
\hline 58 & Lenoir, 2019 & Japan & $\begin{array}{l}\text { Conference } \\
\text { paper }\end{array}$ & $\begin{array}{l}\text { System } \\
\text { design }\end{array}$ & $\begin{array}{l}\text { Monitoring abnormal } \\
\text { events }\end{array}$ & loT & Residents \\
\hline 59 & Shen, 2019 & China & $\begin{array}{l}\text { Journal } \\
\text { article }\end{array}$ & $\begin{array}{l}\text { System } \\
\text { design }\end{array}$ & $\begin{array}{l}\text { Monitoring abnormal } \\
\text { events }\end{array}$ & loT & Residents \\
\hline 60 & $\begin{array}{l}\text { Takahashi et } \\
\text { al., } 2019\end{array}$ & Japan & $\begin{array}{l}\text { Conference } \\
\text { paper }\end{array}$ & $\begin{array}{l}\text { System } \\
\text { design }\end{array}$ & $\begin{array}{l}\text { Monitoring abnormal } \\
\text { events (only } \\
\text { location) }\end{array}$ & loT & Residents \\
\hline 61 & $\begin{array}{l}\text { Tang et al., } \\
2019\end{array}$ & China & $\begin{array}{l}\text { Journal } \\
\text { article }\end{array}$ & $\begin{array}{l}\text { System } \\
\text { design }\end{array}$ & $\begin{array}{l}\text { Monitoring abnormal } \\
\text { events }\end{array}$ & loT & Residents \\
\hline 62 & $\begin{array}{l}\text { Toda \& } \\
\text { Shinomiya, } \\
2019\end{array}$ & Japan & $\begin{array}{l}\text { Conference } \\
\text { paper }\end{array}$ & $\begin{array}{l}\text { System } \\
\text { design }\end{array}$ & Fall detection & loT & Residents \\
\hline 63 & Xiao, 2019 & China & Thesis & $\begin{array}{l}\text { System } \\
\text { design }\end{array}$ & $\begin{array}{l}\text { Monitoring abnormal } \\
\text { events }\end{array}$ & loT & Residents \\
\hline & & & & & (Smart mattress) & & \\
\hline 64 & $\begin{array}{l}\text { Xu \& Tuo, } \\
2019\end{array}$ & China & $\begin{array}{l}\text { Journal } \\
\text { article }\end{array}$ & $\begin{array}{l}\text { Non-research } \\
\text { article }\end{array}$ & $\begin{array}{l}\text { Monitoring abnormal } \\
\text { events }\end{array}$ & loT & Residents \\
\hline 65 & $\begin{array}{l}\text { Yoo et al., } \\
2019\end{array}$ & $\begin{array}{l}\text { South } \\
\text { Korea }\end{array}$ & $\begin{array}{l}\text { Conference } \\
\text { paper }\end{array}$ & $\begin{array}{l}\text { System } \\
\text { design }\end{array}$ & $\begin{array}{l}\text { Monitoring abnormal } \\
\text { events }\end{array}$ & loT & Residents \\
\hline 66 & $\begin{array}{l}\text { Buisseret et } \\
\text { al. } 2020\end{array}$ & Belgium & $\begin{array}{l}\text { Journal } \\
\text { article }\end{array}$ & $\begin{array}{l}\text { System } \\
\text { design }\end{array}$ & Fall prediction & $\begin{array}{l}\text { Big data and } \\
\text { Al }\end{array}$ & Residents \\
\hline 67 & $\begin{array}{l}\text { Chen et al. } \\
2021\end{array}$ & China & $\begin{array}{l}\text { Conference } \\
\text { paper }\end{array}$ & $\begin{array}{l}\text { System } \\
\text { design }\end{array}$ & Fall prediction & $\begin{array}{l}\text { Big data and } \\
\text { Al }\end{array}$ & Residents \\
\hline 68 & Gharti 2020 & Australia & $\begin{array}{l}\text { Conference } \\
\text { Paper }\end{array}$ & $\begin{array}{l}\text { Non-research } \\
\text { article }\end{array}$ & Fall detection & IoT & Residents \\
\hline 69 & $\begin{array}{l}\text { Lanza et al. } \\
2020\end{array}$ & Italy & $\begin{array}{l}\text { Journal } \\
\text { article }\end{array}$ & $\begin{array}{l}\text { System } \\
\text { design }\end{array}$ & $\begin{array}{l}\text { Monitoring abnormal } \\
\text { events }\end{array}$ & $\begin{array}{l}\text { Big data and } \\
\text { Al }\end{array}$ & Residents \\
\hline 70 & $\begin{array}{l}\text { Lee et al. } \\
2020\end{array}$ & $\begin{array}{l}\text { South } \\
\text { Korea }\end{array}$ & $\begin{array}{l}\text { Journal } \\
\text { article }\end{array}$ & $\begin{array}{l}\text { System } \\
\text { design }\end{array}$ & Fall prediction & $\begin{array}{l}\text { Big data and } \\
\text { Al }\end{array}$ & $\mathrm{HCPs}^{\mathrm{e}}$ \\
\hline 71 & $\begin{array}{l}\text { Mishkhal et } \\
\text { al. } 2020\end{array}$ & Iraq & $\begin{array}{l}\text { Conference } \\
\text { paper }\end{array}$ & $\begin{array}{l}\text { System } \\
\text { design }\end{array}$ & Fall prediction & loT & Residents \\
\hline 72 & $\begin{array}{l}\text { Suzuki et al. } \\
2020\end{array}$ & Japan & $\begin{array}{l}\text { Journal } \\
\text { article }\end{array}$ & $\begin{array}{l}\text { Non- } \\
\text { experimental }^{f}\end{array}$ & Fall prediction & $\begin{array}{l}\text { Big data and } \\
\text { Al }\end{array}$ & Residents \\
\hline 73 & Wang, 2020 & China & Thesis & $\begin{array}{l}\text { System } \\
\text { design }\end{array}$ & $\begin{array}{l}\text { Monitoring abnormal } \\
\text { events }\end{array}$ & loT & Residents \\
\hline
\end{tabular}




\begin{tabular}{|c|c|c|c|c|c|c|c|c|}
\hline 74 & $\begin{array}{l}\text { Wan et al. } \\
2021\end{array}$ & China & $\begin{array}{l}\text { Journal } \\
\text { article }\end{array}$ & $\begin{array}{l}\text { System } \\
\text { design }\end{array}$ & Fall detection & IoT & Residents & \\
\hline 75 & $\begin{array}{l}\text { Chen et al. } \\
2021\end{array}$ & $\begin{array}{l}\text { Taiwan, } \\
\text { China }\end{array}$ & $\begin{array}{l}\text { Conference } \\
\text { paper }\end{array}$ & $\begin{array}{l}\text { System } \\
\text { design }\end{array}$ & $\begin{array}{l}\text { Monitoring abnormal } \\
\text { events }\end{array}$ & IoT & Residents & \\
\hline 76 & $\begin{array}{l}\text { Flores-Martin } \\
\text { et al. } 2021\end{array}$ & Spain & $\begin{array}{l}\text { Journal } \\
\text { article }\end{array}$ & $\begin{array}{l}\text { System } \\
\text { design }\end{array}$ & $\begin{array}{l}\text { Monitoring abnormal } \\
\text { events }\end{array}$ & IoT & Residents & \\
\hline 77 & $\begin{array}{l}\text { Chan et al., } \\
2001\end{array}$ & China & $\begin{array}{l}\text { Journal } \\
\text { article }\end{array}$ & $\begin{array}{l}\text { Non- } \\
\text { experimental }\end{array}$ & Telemedicine & Digital health & Residents & \multirow{24}{*}{$\begin{array}{l}\text { Remote } \\
\text { clinical } \\
\text { services } \\
\text { through } \\
\text { digital health }\end{array}$} \\
\hline 78 & $\begin{array}{l}\text { Pallawala \& } \\
\text { Lun, } 2001\end{array}$ & Singapore & $\begin{array}{l}\text { Journal } \\
\text { article }\end{array}$ & $\begin{array}{l}\text { Non- } \\
\text { experimental }\end{array}$ & Telemedicine & Digital health & Residents & \\
\hline 79 & $\begin{array}{l}\text { Weiner et al., } \\
2001\end{array}$ & USA & $\begin{array}{l}\text { Journal } \\
\text { article }\end{array}$ & Experimental & Telemedicine & Digital health & Residents & \\
\hline 80 & $\begin{array}{l}\text { Hui \& Woo, } \\
2002\end{array}$ & China & $\begin{array}{l}\text { Journal } \\
\text { article }\end{array}$ & $\begin{array}{l}\text { Non- } \\
\text { experimental }\end{array}$ & Telemedicine & Digital health & Residents & \\
\hline 81 & $\begin{array}{l}\text { Savenstedt } \\
\text { et al., } 2002\end{array}$ & Sweden & $\begin{array}{l}\text { Journal } \\
\text { article }\end{array}$ & Qualitative & Telemedicine & Digital health & Residents & \\
\hline 82 & $\begin{array}{l}\text { Weiner et al., } \\
2003\end{array}$ & USA & $\begin{array}{l}\text { Conference } \\
\text { paper }\end{array}$ & Experimental & Telemedicine & Digital health & Residents & \\
\hline 83 & $\begin{array}{l}\text { Zelickson, } \\
2003\end{array}$ & USA & $\begin{array}{l}\text { Journal } \\
\text { article }\end{array}$ & $\begin{array}{l}\text { Non- } \\
\text { experimental }\end{array}$ & Telemedicine & Digital health & Residents & \\
\hline 84 & $\begin{array}{l}\text { Armer et al., } \\
2004\end{array}$ & USA & $\begin{array}{l}\text { Journal } \\
\text { article }\end{array}$ & Experimental & Telemedicine & Digital health & Residents & \\
\hline 85 & $\begin{array}{l}\text { Savenstedt } \\
\text { et al., } 2004\end{array}$ & Sweden & $\begin{array}{l}\text { Journal } \\
\text { article }\end{array}$ & Qualitative & Telemedicine & Digital health & Residents & \\
\hline 86 & $\begin{array}{l}\text { Daly et al., } \\
2005\end{array}$ & USA & $\begin{array}{l}\text { Journal } \\
\text { article }\end{array}$ & $\begin{array}{l}\text { Non-research } \\
\text { article }\end{array}$ & Telemedicine & Digital health & Residents & \\
\hline 87 & $\begin{array}{l}\text { Lavanya et } \\
\text { al., } 2006\end{array}$ & Singapore & $\begin{array}{l}\text { Conference } \\
\text { paper }\end{array}$ & $\begin{array}{l}\text { Non- } \\
\text { experimental }\end{array}$ & $\begin{array}{l}\text { Teledermatology } \\
\text { (Clinical assessment } \\
\text { system) }\end{array}$ & Digital health & $\begin{array}{l}\text { Nurses and } \\
\text { dermatologists }\end{array}$ & \\
\hline 88 & $\begin{array}{l}\text { Loeb et al., } \\
2006\end{array}$ & Canada & $\begin{array}{l}\text { Journal } \\
\text { article }\end{array}$ & $\begin{array}{l}\text { Non- } \\
\text { experimental }\end{array}$ & $\begin{array}{l}\text { Telemedicine } \\
\text { (Mobile x-ray) }\end{array}$ & Digital health & Residents & \\
\hline 89 & $\begin{array}{l}\text { Shulman et } \\
\text { al., } 2006\end{array}$ & Canada & $\begin{array}{l}\text { Conference } \\
\text { paper }\end{array}$ & $\begin{array}{l}\text { Non-research } \\
\text { article }\end{array}$ & Telemedicine & Digital health & Residents & \\
\hline 90 & $\begin{array}{l}\text { Cusack et al., } \\
2008\end{array}$ & USA & $\begin{array}{l}\text { Journal } \\
\text { article }\end{array}$ & $\begin{array}{l}\text { Non- } \\
\text { experimental }\end{array}$ & Telemedicine & Digital health & Residents & \\
\hline 91 & $\begin{array}{l}\text { Janardhanan } \\
\text { et al., } 2008\end{array}$ & Singapore & $\begin{array}{l}\text { Journal } \\
\text { article }\end{array}$ & $\begin{array}{l}\text { Non- } \\
\text { experimental }\end{array}$ & Telemedicine & Digital health & Residents & \\
\hline 92 & $\begin{array}{l}\text { Biglan et al., } \\
2009\end{array}$ & USA & $\begin{array}{l}\text { Journal } \\
\text { article }\end{array}$ & Qualitative & Telemedicine & Digital health & Residents & \\
\hline 93 & $\begin{array}{l}\text { Chang et al., } \\
2009\end{array}$ & $\begin{array}{l}\text { Taiwan, } \\
\text { China }\end{array}$ & $\begin{array}{l}\text { Journal } \\
\text { article }\end{array}$ & $\begin{array}{l}\text { Non- } \\
\text { experimental }\end{array}$ & Telemedicine & Digital health & Residents & \\
\hline 94 & $\begin{array}{l}\text { Qadri et al., } \\
2009\end{array}$ & USA & $\begin{array}{l}\text { Journal } \\
\text { article }\end{array}$ & $\begin{array}{l}\text { Mixed } \\
\text { methods }\end{array}$ & $\begin{array}{l}\text { Telemedicine } \\
\text { (Clinical assessment } \\
\text { system) }\end{array}$ & Digital health & Nurses & \\
\hline 95 & $\begin{array}{l}\text { Chang et al., } \\
2010\end{array}$ & $\begin{array}{l}\text { Taiwan, } \\
\text { China }\end{array}$ & $\begin{array}{l}\text { Journal } \\
\text { article }\end{array}$ & $\begin{array}{l}\text { Non- } \\
\text { experimental }\end{array}$ & Telemedicine & Digital health & Residents & \\
\hline 96 & $\begin{array}{l}\text { Rabinowitz } \\
\text { et al., } 2010\end{array}$ & USA & $\begin{array}{l}\text { Journal } \\
\text { article }\end{array}$ & $\begin{array}{l}\text { Non- } \\
\text { experimental }\end{array}$ & Telemedicine & Digital health & Residents & \\
\hline 97 & $\begin{array}{l}\text { Wälivaara et } \\
\text { al., } 2011\end{array}$ & Sweden & $\begin{array}{l}\text { Journal } \\
\text { article }\end{array}$ & Qualitative & Telemedicine & Digital health & Residents & \\
\hline 98 & $\begin{array}{l}\text { Eklund et al., } \\
2012\end{array}$ & Sweden & $\begin{array}{l}\text { Journal } \\
\text { article }\end{array}$ & $\begin{array}{l}\text { Non- } \\
\text { experimental }\end{array}$ & $\begin{array}{l}\text { Telemedicine } \\
\text { (Mobile X-ray) }\end{array}$ & Digital health & Residents & \\
\hline 99 & $\begin{array}{l}\text { Gray et al., } \\
2012\end{array}$ & Australia & $\begin{array}{l}\text { Journal } \\
\text { article }\end{array}$ & $\begin{array}{l}\text { Non- } \\
\text { experimental }\end{array}$ & Telemedicine & Digital health & Residents & \\
\hline 100 & Handler et & USA & Journal & Non- & Telemedicine & Digital health & Residents & \\
\hline
\end{tabular}

Page 22/36 


\begin{tabular}{|c|c|c|c|c|c|c|c|}
\hline & al., 2013 & & article & experimental & & & \\
\hline 101 & $\begin{array}{l}\text { Novak et al., } \\
2013\end{array}$ & USA & $\begin{array}{l}\text { Conference } \\
\text { paper }\end{array}$ & Experimental & Telemedicine & Digital health & Residents \\
\hline 102 & $\begin{array}{l}\text { Vowden \& } \\
\text { Vowden, } \\
2013\end{array}$ & UK & $\begin{array}{l}\text { Journal } \\
\text { article }\end{array}$ & Experimental & Telemedicine & Digital health & Residents \\
\hline 103 & $\begin{array}{l}\text { Catic et al., } \\
2014\end{array}$ & USA & $\begin{array}{l}\text { Journal } \\
\text { article }\end{array}$ & $\begin{array}{l}\text { Non- } \\
\text { experimental }\end{array}$ & Telemedicine & Digital health & Residents \\
\hline 104 & $\begin{array}{l}\text { Grabowski \& } \\
\text { O'Malley, } \\
2014\end{array}$ & USA & $\begin{array}{l}\text { Journal } \\
\text { article }\end{array}$ & Experimental & Telemedicine & Digital health & Residents \\
\hline 105 & $\begin{array}{l}\text { Crotty et al., } \\
2014\end{array}$ & Australia & $\begin{array}{l}\text { Journal } \\
\text { article }\end{array}$ & Experimental & Telemedicine & Digital health & Residents \\
\hline 106 & $\begin{array}{l}\text { Doumbouya } \\
\text { et al., } 2015\end{array}$ & France & $\begin{array}{l}\text { Journal } \\
\text { article }\end{array}$ & $\begin{array}{l}\text { System } \\
\text { design }\end{array}$ & Telemedicine & Digital health & Residents \\
\hline 107 & $\begin{array}{l}\text { F. Huang et } \\
\text { al., } 2015\end{array}$ & $\begin{array}{l}\text { Taiwan, } \\
\text { China }\end{array}$ & $\begin{array}{l}\text { Journal } \\
\text { article }\end{array}$ & Experimental & Telemedicine & Digital health & Residents \\
\hline 108 & $\begin{array}{l}\text { Montalto et } \\
\text { al., } 2015\end{array}$ & Australia & $\begin{array}{l}\text { Conference } \\
\text { paper }\end{array}$ & $\begin{array}{l}\text { Non- } \\
\text { experimental }\end{array}$ & $\begin{array}{l}\text { Telemedicine } \\
\text { (Mobile X-ray) }\end{array}$ & Digital health & Residents \\
\hline 109 & $\begin{array}{l}\text { Toh et al., } \\
2015 b\end{array}$ & Singapore & $\begin{array}{l}\text { Conference } \\
\text { paper }\end{array}$ & Qualitative & Telemedicine & Digital health & Residents \\
\hline 110 & $\begin{array}{l}\text { Toh et al., } \\
2015 a\end{array}$ & Singapore & $\begin{array}{l}\text { Conference } \\
\text { paper }\end{array}$ & $\begin{array}{l}\text { Non- } \\
\text { experimental }\end{array}$ & Telemedicine & Digital health & Residents \\
\hline 111 & Volicer, 2015 & USA & $\begin{array}{l}\text { Journal } \\
\text { article }\end{array}$ & $\begin{array}{l}\text { Non-research } \\
\text { article }\end{array}$ & Telemedicine & Digital health & Residents \\
\hline 112 & $\begin{array}{l}\text { De Luca et } \\
\text { al., } 2016\end{array}$ & Italy & $\begin{array}{l}\text { Journal } \\
\text { article }\end{array}$ & Experimental & Telemedicine & Digital health & Residents \\
\hline 113 & $\begin{array}{l}\text { Dozet et al., } \\
2016\end{array}$ & Sweden & $\begin{array}{l}\text { Journal } \\
\text { article }\end{array}$ & $\begin{array}{l}\text { Non- } \\
\text { experimental }\end{array}$ & $\begin{array}{l}\text { Telemedicine } \\
\text { (Mobile X-ray) }\end{array}$ & Digital health & Residents \\
\hline 114 & $\begin{array}{l}\text { Driessen et } \\
\text { al., } 2016\end{array}$ & USA & $\begin{array}{l}\text { Journal } \\
\text { article }\end{array}$ & $\begin{array}{l}\text { Non- } \\
\text { experimental }\end{array}$ & Telemedicine & Digital health & Residents \\
\hline 115 & $\begin{array}{l}\text { Gaglio et al., } \\
2016\end{array}$ & France & $\begin{array}{l}\text { Conference } \\
\text { paper }\end{array}$ & Qualitative & Telemedicine & Digital health & Residents \\
\hline 116 & $\begin{array}{l}\text { Gillespie et } \\
\text { al., } 2016\end{array}$ & USA & $\begin{array}{l}\text { Journal } \\
\text { article }\end{array}$ & $\begin{array}{l}\text { Non- } \\
\text { experimental }\end{array}$ & Telemedicine & Digital health & Residents \\
\hline 117 & Morley, 2016 & USA & $\begin{array}{l}\text { Journal } \\
\text { article }\end{array}$ & $\begin{array}{l}\text { Non-research } \\
\text { article }\end{array}$ & Telemedicine & Digital health & Residents \\
\hline 118 & $\begin{array}{l}\text { Schneider et } \\
\text { al., } 2016\end{array}$ & USA & $\begin{array}{l}\text { Journal } \\
\text { article }\end{array}$ & $\begin{array}{l}\text { Non- } \\
\text { experimental }\end{array}$ & Telemedicine & Digital health & Residents \\
\hline 119 & $\begin{array}{l}\text { Kjelle \& } \\
\text { Lysdahl, } \\
2017\end{array}$ & Norway & $\begin{array}{l}\text { Journal } \\
\text { article }\end{array}$ & $\begin{array}{l}\text { Non-research } \\
\text { article }\end{array}$ & $\begin{array}{l}\text { Telemedicine } \\
\text { (Mobile X-ray) }\end{array}$ & Digital health & Residents \\
\hline 120 & $\begin{array}{l}\text { Newbould et } \\
\text { al., } 2017\end{array}$ & UK & Book & $\begin{array}{l}\text { Non- } \\
\text { experimental }\end{array}$ & Telemedicine & Digital health & Residents \\
\hline 121 & $\begin{array}{l}\text { Queyroux et } \\
\text { al., } 2017\end{array}$ & France & $\begin{array}{l}\text { Journal } \\
\text { article }\end{array}$ & $\begin{array}{l}\text { Non- } \\
\text { experimental }\end{array}$ & Telemedicine & Digital health & Residents \\
\hline 122 & $\begin{array}{l}\text { Delmastro et } \\
\text { al., } 2018\end{array}$ & Italy & $\begin{array}{l}\text { Conference } \\
\text { paper }\end{array}$ & $\begin{array}{l}\text { Non- } \\
\text { experimental }\end{array}$ & Telemedicine & Digital health & Residents \\
\hline 123 & $\begin{array}{l}\text { Kjelle et al., } \\
2018\end{array}$ & Norway & $\begin{array}{l}\text { Journal } \\
\text { article }\end{array}$ & Qualitative & $\begin{array}{l}\text { Telemedicine } \\
\text { (Mobile X-ray) }\end{array}$ & Digital health & Residents \\
\hline 124 & $\begin{array}{l}\text { Esteves et al., } \\
2019\end{array}$ & Portugal & $\begin{array}{l}\text { Journal } \\
\text { article }\end{array}$ & $\begin{array}{l}\text { System } \\
\text { design }\end{array}$ & Telemedicine & Digital health & HCPs \\
\hline 125 & $\begin{array}{l}\text { Gentry et al., } \\
2019\end{array}$ & USA & $\begin{array}{l}\text { Journal } \\
\text { article }\end{array}$ & $\begin{array}{l}\text { Non-research } \\
\text { article }\end{array}$ & Telemedicine & Digital health & Residents \\
\hline
\end{tabular}




\begin{tabular}{|c|c|c|c|c|c|c|c|c|}
\hline 126 & $\begin{array}{l}\text { Ozkaynak et } \\
\text { al., } 2019\end{array}$ & USA & $\begin{array}{l}\text { Journal } \\
\text { article }\end{array}$ & Qualitative & $\begin{array}{l}\text { Telemedicine(Clinical } \\
\text { assessment system) }\end{array}$ & Digital health & NH staffs & \\
\hline 127 & $\begin{array}{l}\text { Shafiee } \\
\text { Hanjani et } \\
\text { al., } 2019\end{array}$ & Australia & $\begin{array}{l}\text { Journal } \\
\text { article }\end{array}$ & $\begin{array}{l}\text { Mixed } \\
\text { methods }\end{array}$ & Telemedicine & Digital health & Residents & \\
\hline 128 & $\begin{array}{l}\text { Cormi et al. } \\
2020\end{array}$ & France & $\begin{array}{l}\text { Journal } \\
\text { article }\end{array}$ & $\begin{array}{l}\text { Non-research } \\
\text { article }\end{array}$ & Telemedicine & Digital health & Residents & \\
\hline 129 & $\begin{array}{l}\text { Lai et al. } \\
2020\end{array}$ & USA & $\begin{array}{l}\text { Journal } \\
\text { article }\end{array}$ & $\begin{array}{l}\text { Non- } \\
\text { experimental }\end{array}$ & Teleophthalmology & Digital health & Residents & \\
\hline 130 & $\begin{array}{l}\text { Low et al. } \\
2020\end{array}$ & Singapore & $\begin{array}{l}\text { Journal } \\
\text { article }\end{array}$ & $\begin{array}{l}\text { Non- } \\
\text { experimental }\end{array}$ & Telemedicine & Digital health & Residents & \\
\hline 131 & $\begin{array}{l}\text { Ohligs et al. } \\
2020\end{array}$ & Germany & $\begin{array}{l}\text { Journal } \\
\text { article }\end{array}$ & $\begin{array}{l}\text { Non- } \\
\text { experimental }\end{array}$ & Telemedicine & Digital health & Residents & \\
\hline 132 & $\begin{array}{l}\text { Alexander et } \\
\text { al. } 2021\end{array}$ & USA & $\begin{array}{l}\text { Journal } \\
\text { article }\end{array}$ & $\begin{array}{l}\text { Non- } \\
\text { experimental }\end{array}$ & Telemedicine & Digital health & Residents & \\
\hline 133 & $\begin{array}{l}\text { Okamoto et } \\
\text { al. } 2021\end{array}$ & USA & $\begin{array}{l}\text { Conference } \\
\text { paper }\end{array}$ & $\begin{array}{l}\text { Non research } \\
\text { article }\end{array}$ & Telemedicine & Digital health & Residents & \\
\hline 134 & $\begin{array}{l}\text { Lenderink \& } \\
\text { Egberts, } \\
2004\end{array}$ & Netherlands & $\begin{array}{l}\text { Journal } \\
\text { article }\end{array}$ & $\begin{array}{l}\text { Non- } \\
\text { experimental }\end{array}$ & $\begin{array}{l}\text { Information } \\
\text { management and } \\
\text { decision making }\end{array}$ & $\mathrm{IMS}^{\mathrm{g}}$ & Nurses & \multirow{14}{*}{$\begin{array}{l}\text { Information } \\
\text { management } \\
\text { and decision } \\
\text { making }\end{array}$} \\
\hline 135 & $\begin{array}{l}\text { Alexander, } \\
2005\end{array}$ & USA & Thesis & $\begin{array}{l}\text { Non- } \\
\text { experimental }\end{array}$ & $\begin{array}{l}\text { Information } \\
\text { management and } \\
\text { decision making }\end{array}$ & IMS & $\begin{array}{l}\text { Administrative } \\
\text { staffs }\end{array}$ & \\
\hline 136 & Byrne, 2005 & USA & Thesis & Experimental & $\begin{array}{l}\text { Information } \\
\text { management and } \\
\text { decision making }\end{array}$ & IMS & $\mathrm{NH}$ staffs & \\
\hline 137 & $\begin{array}{l}\text { Celler et al., } \\
2006\end{array}$ & Australia & $\begin{array}{l}\text { Conference } \\
\text { paper }\end{array}$ & $\begin{array}{l}\text { Non- } \\
\text { experimental }\end{array}$ & $\begin{array}{l}\text { Information } \\
\text { management and } \\
\text { decision making }\end{array}$ & IMS & $\mathrm{NH}$ staffs & \\
\hline 138 & Cherry, 2006 & USA & Thesis & Qualitative & $\begin{array}{l}\text { Information } \\
\text { management and } \\
\text { decision making }\end{array}$ & IMS & HCPs & \\
\hline 139 & $\begin{array}{l}\text { Alexander et } \\
\text { al., } 2007\end{array}$ & USA & $\begin{array}{l}\text { Journal } \\
\text { article }\end{array}$ & Qualitative & $\begin{array}{l}\text { Information } \\
\text { management and } \\
\text { decision making }\end{array}$ & IMS & $\mathrm{NH}$ staffs & \\
\hline 140 & $\begin{array}{l}\text { Alexander, } \\
2008\end{array}$ & USA & $\begin{array}{l}\text { Journal } \\
\text { article }\end{array}$ & $\begin{array}{l}\text { Non- } \\
\text { experimental }\end{array}$ & $\begin{array}{l}\text { Information } \\
\text { management and } \\
\text { decision making }\end{array}$ & IMS & NH staffs & \\
\hline 141 & $\begin{array}{l}\text { Breen \& } \\
\text { Zhang, } 2008\end{array}$ & USA & $\begin{array}{l}\text { Journal } \\
\text { article }\end{array}$ & $\begin{array}{l}\text { Non-research } \\
\text { article }\end{array}$ & $\begin{array}{l}\text { Information } \\
\text { management and } \\
\text { decision making }\end{array}$ & IMS & $\begin{array}{l}\text { Nurses and } \\
\text { other medical } \\
\text { practitioners }\end{array}$ & \\
\hline 142 & $\begin{array}{l}\text { Yu et al., } \\
2008\end{array}$ & China & $\begin{array}{l}\text { Journal } \\
\text { article }\end{array}$ & $\begin{array}{l}\text { Mixed } \\
\text { methods }\end{array}$ & $\begin{array}{l}\text { Information } \\
\text { management and } \\
\text { decision making }\end{array}$ & IMS & Caregivers & \\
\hline 143 & $\begin{array}{l}\text { Sax \& } \\
\text { Lawrence, } \\
2009\end{array}$ & Australia & $\begin{array}{l}\text { Conference } \\
\text { paper }\end{array}$ & $\begin{array}{l}\text { System } \\
\text { design }\end{array}$ & $\begin{array}{l}\text { Information } \\
\text { management and } \\
\text { decision making }\end{array}$ & IMS & Nurses & \\
\hline 144 & $\begin{array}{l}\text { Scott- } \\
\text { Cawiezell et } \\
\text { al., } 2009\end{array}$ & USA & $\begin{array}{l}\text { Journal } \\
\text { article }\end{array}$ & $\begin{array}{l}\text { Non- } \\
\text { experimental }\end{array}$ & $\begin{array}{l}\text { Information } \\
\text { management and } \\
\text { decision making }\end{array}$ & IMS & $\begin{array}{l}\text { Practitioners, } \\
\text { nursing staffs, } \\
\text { medication } \\
\text { administrators } \\
\text { and NH } \\
\text { leadership }\end{array}$ & \\
\hline 145 & Ohol, 2010 & USA & Thesis & $\begin{array}{l}\text { System } \\
\text { design }\end{array}$ & $\begin{array}{l}\text { Information } \\
\text { management and } \\
\text { decision making }\end{array}$ & IMS & Clinical staffs & \\
\hline 146 & $\begin{array}{l}\text { Matusitz et } \\
\text { al., } 2013\end{array}$ & USA & $\begin{array}{l}\text { Journal } \\
\text { article }\end{array}$ & $\begin{array}{l}\text { Non-research } \\
\text { article }\end{array}$ & $\begin{array}{l}\text { Information } \\
\text { management and } \\
\text { decision making }\end{array}$ & IMS & $\begin{array}{l}\text { Healthcare } \\
\text { practitioners }\end{array}$ & \\
\hline 147 & $\begin{array}{l}\text { Alexander et } \\
\text { al., } 2015\end{array}$ & USA & $\begin{array}{l}\text { Journal } \\
\text { article }\end{array}$ & Qualitative & $\begin{array}{l}\text { Information } \\
\text { management and } \\
\text { decision making }\end{array}$ & IMS & Clinical staffs & \\
\hline
\end{tabular}




\begin{tabular}{|c|c|c|c|c|c|c|c|c|}
\hline 148 & $\begin{array}{l}\text { Z. Huang et } \\
\text { al., } 2015\end{array}$ & China & $\begin{array}{l}\text { Journal } \\
\text { article }\end{array}$ & $\begin{array}{l}\text { System } \\
\text { design }\end{array}$ & $\begin{array}{l}\text { Information } \\
\text { management and } \\
\text { decision making }\end{array}$ & IMS & $\begin{array}{l}\mathrm{NH} \text { staffs and } \\
\text { administration }\end{array}$ & \\
\hline 149 & Wang, 2016 & China & $\begin{array}{l}\text { Journal } \\
\text { article }\end{array}$ & $\begin{array}{l}\text { Non-research } \\
\text { article }\end{array}$ & $\begin{array}{l}\text { Information } \\
\text { management and } \\
\text { decision making }\end{array}$ & IMS & $\begin{array}{l}\text { HCPs and } \\
\text { administration }\end{array}$ & \\
\hline 150 & Zhang, 2017 & China & Thesis & $\begin{array}{l}\text { System } \\
\text { design }\end{array}$ & $\begin{array}{l}\text { Information } \\
\text { management and } \\
\text { decision making }\end{array}$ & IMS & $\begin{array}{l}\text { Doctors, } \\
\text { nurses and } \\
\text { caregivers }\end{array}$ & \\
\hline 151 & Xie, 2016 & China & Thesis & $\begin{array}{l}\text { System } \\
\text { design }\end{array}$ & $\begin{array}{l}\text { Information } \\
\text { management and } \\
\text { decision making }\end{array}$ & IMS & Caregivers & \\
\hline 152 & $\begin{array}{l}\text { Ausserhofer } \\
\text { et al. } 2021\end{array}$ & Switzerland & $\begin{array}{l}\text { Journal } \\
\text { article }\end{array}$ & $\begin{array}{l}\text { Non- } \\
\text { experimental }\end{array}$ & $\begin{array}{l}\text { Information } \\
\text { management and } \\
\text { decision making }\end{array}$ & IMS & $\begin{array}{l}\text { Care workers } \\
\text { and nurses }\end{array}$ & \\
\hline 153 & $\begin{array}{l}\text { Kei Hong et } \\
\text { al. } 2021\end{array}$ & China & $\begin{array}{l}\text { Journal } \\
\text { article }\end{array}$ & $\begin{array}{l}\text { Non- } \\
\text { experimental }\end{array}$ & $\begin{array}{l}\text { Information } \\
\text { management and } \\
\text { decision making }\end{array}$ & IMS & HCPs & \\
\hline 154 & $\begin{array}{l}\text { Masuda \& } \\
\text { Numao, } 2017\end{array}$ & Japan & $\begin{array}{l}\text { Conference } \\
\text { paper }\end{array}$ & $\begin{array}{l}\text { System } \\
\text { design }\end{array}$ & $\begin{array}{l}\text { Clinical data } \\
\text { anaylsis (Diagnosis) }\end{array}$ & loT & Residents & \multirow{5}{*}{$\begin{array}{l}\text { Clinical data } \\
\text { analysis by } \\
\text { Al }\end{array}$} \\
\hline 155 & $\begin{array}{l}\text { Roh \& Park, } \\
2017\end{array}$ & $\begin{array}{l}\text { South } \\
\text { Korea }\end{array}$ & $\begin{array}{l}\text { Journal } \\
\text { article }\end{array}$ & $\begin{array}{l}\text { System } \\
\text { design }\end{array}$ & $\begin{array}{l}\text { Quality of Life } \\
\text { measurements }\end{array}$ & $\begin{array}{l}\text { Big data and } \\
\text { Al }\end{array}$ & HCPs & \\
\hline 156 & $\begin{array}{l}\text { González et } \\
\text { al., } 2019\end{array}$ & Spain & $\begin{array}{l}\text { Journal } \\
\text { article }\end{array}$ & $\begin{array}{l}\text { System } \\
\text { design }\end{array}$ & $\begin{array}{l}\text { Clinical data } \\
\text { anaylsis (frailty and } \\
\text { cognition status) }\end{array}$ & loT & HCPs & \\
\hline 157 & $\begin{array}{l}\text { Kokubo \& } \\
\text { Kamiya, } \\
2019\end{array}$ & USA & $\begin{array}{l}\text { Conference } \\
\text { paper }\end{array}$ & $\begin{array}{l}\text { Non- } \\
\text { experimental }\end{array}$ & $\begin{array}{l}\text { A new signal } \\
\text { parameter } \\
\text { estimation algorithm } \\
\text { for vital signs } \\
\text { monitoring }\end{array}$ & $\begin{array}{l}\text { Big data and } \\
\text { Al }\end{array}$ & HCPs & \\
\hline 158 & $\begin{array}{l}\text { Ambagtsheer } \\
\text { et al., } 2020\end{array}$ & Australia & $\begin{array}{l}\text { Journal } \\
\text { article }\end{array}$ & $\begin{array}{l}\text { Non- } \\
\text { experimental }\end{array}$ & $\begin{array}{l}\text { Identifying frailty by } \\
\text { using artificial } \\
\text { intelligence (Al) } \\
\text { algorithms }\end{array}$ & $\begin{array}{l}\text { Big data and } \\
\text { Al }\end{array}$ & HCPs & \\
\hline 159 & $\begin{array}{l}\text { Hsu et al., } \\
2010\end{array}$ & $\begin{array}{l}\text { Taiwan, } \\
\text { China }\end{array}$ & $\begin{array}{l}\text { Journal } \\
\text { article }\end{array}$ & $\begin{array}{l}\text { System } \\
\text { design }\end{array}$ & $\begin{array}{l}\text { ADLs } \\
\text { assistance (Pillbox) }\end{array}$ & loT & Residents & \multirow{4}{*}{$\begin{array}{l}\text { Activities of } \\
\text { daily living } \\
\left(A D L s^{h}\right) \\
\text { assistance }\end{array}$} \\
\hline 160 & $\begin{array}{l}\text { Chang et al., } \\
2011\end{array}$ & $\begin{array}{l}\text { Taiwan, } \\
\text { China }\end{array}$ & $\begin{array}{l}\text { Journal } \\
\text { article }\end{array}$ & $\begin{array}{l}\text { System } \\
\text { design }\end{array}$ & $\begin{array}{l}\text { ADLs assistance } \\
\text { (Pillbox) }\end{array}$ & loT & Residents & \\
\hline 161 & $\begin{array}{l}\text { Sun et al., } \\
2015\end{array}$ & China & $\begin{array}{l}\text { Journal } \\
\text { article }\end{array}$ & $\begin{array}{l}\text { System } \\
\text { design }\end{array}$ & $\begin{array}{l}\text { ADLs assistance } \\
\text { (Intelligent robot) }\end{array}$ & $\begin{array}{l}\text { Computing } \\
\text { technologies }\end{array}$ & Residents & \\
\hline 162 & $\begin{array}{l}\text { Tsai et al., } \\
2017\end{array}$ & $\begin{array}{l}\text { Taiwan, } \\
\text { China }\end{array}$ & $\begin{array}{l}\text { Conference } \\
\text { paper }\end{array}$ & $\begin{array}{l}\text { System } \\
\text { design }\end{array}$ & $\begin{array}{l}\text { ADLs assistance } \\
\text { (Pillbox) }\end{array}$ & loT & Residents & \\
\hline
\end{tabular}

a Residents=Nursing home residents

${ }^{\mathrm{b}} \mathrm{NH}=$ Nursing home

${ }^{c}$ Experimental study: The intervention or implementation of smart technologies with one or more control variables of the research subjects conducted in nursing home setting to measure or compare the effect of this manipulation on the users or medical outcomes

${ }^{\mathrm{d}}$ Non-research article: Non-original research articles such as review, perspective, controversies, and editorial

e HCPs=Healthcare professionals

${ }^{f}$ Non-experimental study: No control, manipulate or prediction of intervention and implementation of smart technologies, and the conclusion came through the interpretation, observation or interactions

g IMS=Information management system

${ }^{\mathrm{h}}$ ADLs=Activities of daily living 
Table 3: Technology Readiness Levels

Page 26/36 


\begin{tabular}{|c|c|c|c|c|c|c|}
\hline No. & Authors and year & Country & $\begin{array}{l}\text { Study } \\
\text { design }\end{array}$ & Function of Technology & $\begin{array}{l}\text { Technologies related to } \\
\text { 'smartness' }\end{array}$ & TRLs \\
\hline 1 & Sun et al., 2015 & China & $\begin{array}{l}\text { System } \\
\text { design }\end{array}$ & Assisting ADLs ${ }^{a}$ & $\begin{array}{l}\text { Computing } \\
\text { technologies }\end{array}$ & $\mathrm{L} 1^{\mathrm{b}}$ \\
\hline 2 & Xie, 2016 & China & $\begin{array}{l}\text { System } \\
\text { design }\end{array}$ & $\begin{array}{l}\text { Information management and } \\
\text { decision making }\end{array}$ & IMS & \\
\hline 3 & Esteves et al., 2019 & Portugal & $\begin{array}{l}\text { System } \\
\text { design }\end{array}$ & Telemedicine & Digital health & \\
\hline 4 & Shen, 2019 & China & $\begin{array}{l}\text { System } \\
\text { design }\end{array}$ & Monitoring abnormal events & loT & \\
\hline 5 & Chen et al. 2021 & $\begin{array}{l}\text { Taiwan, } \\
\text { China }\end{array}$ & $\begin{array}{l}\text { System } \\
\text { design }\end{array}$ & Monitoring abnormal events & loT & \\
\hline 6 & Lin et al., 2008 & $\begin{array}{l}\text { Taiwan, } \\
\text { China }\end{array}$ & $\begin{array}{l}\text { System } \\
\text { design }\end{array}$ & Monitoring abnormal events & loT & $\mathrm{L} 2^{\mathrm{c}}$ \\
\hline 7 & Hu et al., 2009 & USA & $\begin{array}{l}\text { System } \\
\text { design }\end{array}$ & Monitoring abnormal events & loT & \\
\hline 8 & Ohol, 2010 & USA & $\begin{array}{l}\text { System } \\
\text { design }\end{array}$ & $\begin{array}{l}\text { Information management and } \\
\text { decision making }\end{array}$ & IMS & \\
\hline 9 & $\begin{array}{l}\text { Pallikonda Rajasekaran et al., } \\
2010\end{array}$ & India & $\begin{array}{l}\text { System } \\
\text { design }\end{array}$ & Monitoring abnormal events & loT & \\
\hline 10 & Wu \& Huang, 2011 & $\begin{array}{l}\text { Taiwan, } \\
\text { China }\end{array}$ & $\begin{array}{l}\text { System } \\
\text { design }\end{array}$ & Monitoring abnormal events & loT & \\
\hline 11 & Ghorbel et al., 2013 & France & $\begin{array}{l}\text { System } \\
\text { design }\end{array}$ & Notification for specific events & $\begin{array}{l}\text { Computing } \\
\text { technologies }\end{array}$ & \\
\hline 12 & Neuhaeuser \& D'Angelo, 2013 & Germany & $\begin{array}{l}\text { System } \\
\text { design }\end{array}$ & Monitoring abnormal events & IoT & \\
\hline 13 & Chu et al., 2014 & China & $\begin{array}{l}\text { System } \\
\text { design }\end{array}$ & Monitoring abnormal events & loT & \\
\hline 14 & Huang et al., 2015 & China & $\begin{array}{l}\text { System } \\
\text { design }\end{array}$ & $\begin{array}{l}\text { Information management and } \\
\text { decision making }\end{array}$ & IMS & \\
\hline 15 & Yu et al., 2015 & UK & $\begin{array}{l}\text { System } \\
\text { design }\end{array}$ & Monitoring abnormal events & loT & \\
\hline 16 & Roh \& Park, 2017 & $\begin{array}{l}\text { South } \\
\text { Korea }\end{array}$ & $\begin{array}{l}\text { System } \\
\text { design }\end{array}$ & Quality of Life measurements & Big data and $\mathrm{Al}$ & \\
\hline 17 & Flores-Martin et al. 2021 & Spain & $\begin{array}{l}\text { System } \\
\text { design }\end{array}$ & Monitoring abnormal events & IoT & \\
\hline 18 & Sun, 2011 & China & $\begin{array}{l}\text { System } \\
\text { design }\end{array}$ & Monitoring abnormal events & IoT & $L 3^{d}$ \\
\hline 19 & Andò et al., 2015 & Italy & $\begin{array}{l}\text { System } \\
\text { design }\end{array}$ & Monitoring abnormal events & IoT & \\
\hline 20 & Jiang, 2017 & China & $\begin{array}{l}\text { System } \\
\text { design }\end{array}$ & Monitoring abnormal events & IoT & \\
\hline 21 & Mendes et al., 2017 & Portugal & $\begin{array}{l}\text { System } \\
\text { design }\end{array}$ & Monitoring abnormal events & Big data and $\mathrm{Al}$ & \\
\hline 22 & Wu et al., 2017 & China & $\begin{array}{l}\text { System } \\
\text { design }\end{array}$ & Monitoring abnormal events & Computing technology & \\
\hline 23 & Mahfuz et al., 2018 & Canada & $\begin{array}{l}\text { System } \\
\text { design }\end{array}$ & Fall detection & IoT & \\
\hline 24 & Fong et al., 2019 & USA & $\begin{array}{l}\text { System } \\
\text { design }\end{array}$ & Monitoring abnormal events & IoT & \\
\hline 25 & Ghosh et al., 2019 & India & $\begin{array}{l}\text { System } \\
\text { design }\end{array}$ & Monitoring abnormal events & Big data and $\mathrm{Al}$ & \\
\hline 26 & Huang, 2019 & China & $\begin{array}{l}\text { System } \\
\text { design }\end{array}$ & Fall detection & Big data and Al & \\
\hline 27 & Xiao, 2019 & China & $\begin{array}{l}\text { System } \\
\text { design }\end{array}$ & Monitoring abnormal events & IoT & \\
\hline
\end{tabular}

Page 27/36 


\begin{tabular}{|c|c|c|c|c|c|c|}
\hline 28 & Lanza et al. 2020 & Italy & $\begin{array}{l}\text { System } \\
\text { design }\end{array}$ & Monitoring abnormal events & Big data and $\mathrm{Al}$ & \\
\hline 29 & Fischer et al., 2008 & Australia & $\begin{array}{l}\text { System } \\
\text { design }\end{array}$ & Monitoring abnormal events & IoT & $\mathrm{L} 4^{\mathrm{e}}$ \\
\hline 30 & Hsu et al., 2010 & $\begin{array}{l}\text { Taiwan, } \\
\text { China }\end{array}$ & $\begin{array}{l}\text { System } \\
\text { design }\end{array}$ & Assisting ADLs & IoT & \\
\hline 31 & Chang et al., 2011 & $\begin{array}{l}\text { Taiwan, } \\
\text { China }\end{array}$ & $\begin{array}{l}\text { System } \\
\text { design }\end{array}$ & Assisting ADLs & IoT & \\
\hline 32 & Chen \& Li, 2012 & China & $\begin{array}{l}\text { System } \\
\text { design }\end{array}$ & Monitoring abnormal events & loT & \\
\hline 33 & Pan, 2013 & China & $\begin{array}{l}\text { System } \\
\text { design }\end{array}$ & Monitoring abnormal events & loT & \\
\hline 34 & Carvalho et al., 2015 & France & $\begin{array}{l}\text { System } \\
\text { design }\end{array}$ & Monitoring abnormal events & IoT & $L 5^{f}$ \\
\hline 35 & Borelli et al., 2019 & Italy & $\begin{array}{l}\text { System } \\
\text { design }\end{array}$ & Monitoring abnormal events & loT & \\
\hline 36 & Mishkhal et al. 2020 & Iraq & $\begin{array}{l}\text { System } \\
\text { design }\end{array}$ & Fall prediction & loT & \\
\hline 37 & Sax \& Lawrence, 2009 & Australia & $\begin{array}{l}\text { System } \\
\text { design }\end{array}$ & $\begin{array}{l}\text { Information management and } \\
\text { decision making }\end{array}$ & IMS & $L 6^{g}$ \\
\hline 38 & Gower et al., 2011 & Italy & $\begin{array}{l}\text { System } \\
\text { design }\end{array}$ & Monitoring abnormal events & loT & \\
\hline 39 & Lee et al., 2011 & $\begin{array}{l}\text { South } \\
\text { Korea }\end{array}$ & $\begin{array}{l}\text { System } \\
\text { design }\end{array}$ & Monitoring abnormal events & loT & \\
\hline 40 & Wang, 2014 & China & $\begin{array}{l}\text { System } \\
\text { design }\end{array}$ & Monitoring abnormal events & IoT & \\
\hline 41 & Doumbouya et al., 2015 & France & $\begin{array}{l}\text { System } \\
\text { design }\end{array}$ & Telemedicine & Digital health & \\
\hline 42 & Dias et al., 2016 & Brazil & $\begin{array}{l}\text { System } \\
\text { design }\end{array}$ & Fall detection & IoT & \\
\hline 43 & Ansefine et al., 2017 & Indonesia & $\begin{array}{l}\text { System } \\
\text { design }\end{array}$ & Monitoring abnormal events & loT & \\
\hline 44 & Saod et al., 2017 & Malaysia & $\begin{array}{l}\text { System } \\
\text { design }\end{array}$ & Monitoring abnormal events & IoT & \\
\hline 45 & Xie, 2017 & China & $\begin{array}{l}\text { System } \\
\text { design }\end{array}$ & Monitoring abnormal events & Big data and $\mathrm{Al}$ & \\
\hline 46 & Zhang, 2017 & China & $\begin{array}{l}\text { System } \\
\text { design }\end{array}$ & $\begin{array}{l}\text { Information management and } \\
\text { decision making }\end{array}$ & IMS & \\
\hline 47 & Cai \& Wang, 2019 & China & $\begin{array}{l}\text { System } \\
\text { design }\end{array}$ & Fall detection & IoT & \\
\hline 48 & Deng, 2019 & China & $\begin{array}{l}\text { System } \\
\text { design }\end{array}$ & Monitoring abnormal events & loT & \\
\hline 49 & Toda \& Shinomiya, 2019 & Japan & $\begin{array}{l}\text { System } \\
\text { design }\end{array}$ & Fall detection & loT & \\
\hline 50 & Yoo et al., 2019 & $\begin{array}{l}\text { South } \\
\text { Korea }\end{array}$ & $\begin{array}{l}\text { System } \\
\text { design }\end{array}$ & Monitoring abnormal events & loT & \\
\hline 51 & Wang, 2020 & China & $\begin{array}{l}\text { System } \\
\text { design }\end{array}$ & Monitoring abnormal events & loT & \\
\hline 52 & Suzuki et al., 2006 & Japan & $\begin{array}{l}\text { System } \\
\text { design }\end{array}$ & $\begin{array}{l}\text { Monitoring abnormal events } \\
\text { (location) }\end{array}$ & IoT & $\mathrm{L} 7^{\mathrm{h}}$ \\
\hline 53 & Betgé-Brezetz et al., 2009 & USA & $\begin{array}{l}\text { System } \\
\text { design }\end{array}$ & Notification for specific events & $\begin{array}{l}\text { Computing } \\
\text { technologies }\end{array}$ & \\
\hline 54 & Biswas et al., 2009 & Singapore & $\begin{array}{l}\text { System } \\
\text { design }\end{array}$ & Monitoring abnormal events & loT & \\
\hline 55 & Fraile et al., 2010 & Spain & $\begin{array}{l}\text { System } \\
\text { design }\end{array}$ & Monitoring abnormal events & loT & \\
\hline
\end{tabular}

Page 28/36 


\begin{tabular}{|c|c|c|c|c|c|c|}
\hline 56 & Back et al., 2012 & Finland & $\begin{array}{l}\text { System } \\
\text { design }\end{array}$ & Monitoring abnormal events & loT & \\
\hline 57 & Chang et al., 2012 & $\begin{array}{l}\text { Taiwan, } \\
\text { China }\end{array}$ & $\begin{array}{l}\text { System } \\
\text { design }\end{array}$ & Monitoring abnormal events & loT & \\
\hline 58 & Huang et al., 2013 & $\begin{array}{l}\text { Taiwan, } \\
\text { China }\end{array}$ & $\begin{array}{l}\text { System } \\
\text { design }\end{array}$ & Monitoring abnormal events & loT & \\
\hline 59 & Matsui et al., 2013 & USA & $\begin{array}{l}\text { System } \\
\text { design }\end{array}$ & Monitoring abnormal events & Computing technology & \\
\hline 60 & Tseng et al., 2013 & USA & $\begin{array}{l}\text { System } \\
\text { design }\end{array}$ & Monitoring abnormal events & loT & \\
\hline 61 & Liu \& Hsu, 2014 & $\begin{array}{l}\text { Taiwan, } \\
\text { China }\end{array}$ & $\begin{array}{l}\text { System } \\
\text { design }\end{array}$ & Monitoring abnormal events in bed & loT & \\
\hline 62 & Zhu et al., 2014 & Japan & $\begin{array}{l}\text { System } \\
\text { design }\end{array}$ & Monitoring abnormal events & loT & \\
\hline 63 & $\begin{array}{l}\text { Lopez-Samaniego \& Garcia- } \\
\text { Zapirain, } 2016\end{array}$ & Spain & $\begin{array}{l}\text { System } \\
\text { design }\end{array}$ & Monitoring abnormal events & IoT & \\
\hline 64 & Masuda \& Numao, 2017 & Japan & $\begin{array}{l}\text { System } \\
\text { design }\end{array}$ & Clinical data anaylsis (diagnosis) & IoT & \\
\hline 65 & Mendoza et al., 2017 & Philippines & $\begin{array}{l}\text { System } \\
\text { design }\end{array}$ & Monitoring abnormal events & loT & \\
\hline 66 & Tsai et al., 2017 & $\begin{array}{l}\text { Taiwan, } \\
\text { China }\end{array}$ & $\begin{array}{l}\text { System } \\
\text { design }\end{array}$ & Assisting ADLs & IoT & \\
\hline 67 & Bleda et al., 2018 & Spain & $\begin{array}{l}\text { System } \\
\text { design }\end{array}$ & Monitoring abnormal events & loT & \\
\hline 68 & Lee et al., 2018 & $\begin{array}{l}\text { South } \\
\text { Korea }\end{array}$ & $\begin{array}{l}\text { System } \\
\text { design }\end{array}$ & Monitoring abnormal events & loT & \\
\hline 69 & Morita et al., 2018 & Japan & $\begin{array}{l}\text { System } \\
\text { design }\end{array}$ & Monitoring abnormal events & Big data and Al & \\
\hline 70 & Wu et al., 2018 & China & $\begin{array}{l}\text { System } \\
\text { design }\end{array}$ & Monitoring abnormal events & IoT & \\
\hline 71 & Huang et al., 2019 & $\begin{array}{l}\text { Taiwan, } \\
\text { China }\end{array}$ & $\begin{array}{l}\text { System } \\
\text { design }\end{array}$ & Monitoring abnormal events & IoT & \\
\hline 72 & González et al., 2019 & Spain & $\begin{array}{l}\text { System } \\
\text { design }\end{array}$ & $\begin{array}{l}\text { Clinical data anaylsis (frailty and } \\
\text { cognition status) }\end{array}$ & IoT & \\
\hline 73 & Lenoir, 2019 & Japan & $\begin{array}{l}\text { System } \\
\text { design }\end{array}$ & Monitoring abnormal events & IoT & \\
\hline 74 & Takahashi et al., 2019 & Japan & $\begin{array}{l}\text { System } \\
\text { design }\end{array}$ & $\begin{array}{l}\text { Monitoring abnormal events } \\
\text { (location) }\end{array}$ & loT & \\
\hline 75 & Tang et al., 2019 & China & $\begin{array}{l}\text { System } \\
\text { design }\end{array}$ & Monitoring abnormal events & IoT & \\
\hline 76 & Buisseret et al. 2020 & Switzerland & $\begin{array}{l}\text { System } \\
\text { design }\end{array}$ & Fall prediction & Big data and $\mathrm{Al}$ & \\
\hline 77 & Lee et al. 2020 & $\begin{array}{l}\text { South } \\
\text { Korea }\end{array}$ & $\begin{array}{l}\text { System } \\
\text { design }\end{array}$ & Fall prediction & Big data and $\mathrm{Al}$ & \\
\hline 78 & Wan et al. 2021 & China & $\begin{array}{l}\text { System } \\
\text { design }\end{array}$ & Fall detection & IoT & \\
\hline 79 & Montanini et al. 2017 & Italy & $\begin{array}{l}\text { System } \\
\text { design }\end{array}$ & Monitoring abnormal events & IoT & $\begin{array}{l}\text { Not } \\
\text { applicable }\end{array}$ \\
\hline 80 & Danielsen 2016 & Norway & $\begin{array}{l}\text { System } \\
\text { design }\end{array}$ & Monitoring abnormal events & IoT & \\
\hline 81 & Chen et al. 2021 & China & $\begin{array}{l}\text { System } \\
\text { design }\end{array}$ & Fall prediction & Big data and $\mathrm{Al}$ & \\
\hline
\end{tabular}

${ }^{\mathrm{a} A D L s}=$ Activities of daily living

${ }^{b} \mathrm{~L} 1=$ Level 1: Basic principles observed and reported. 
${ }^{\complement} \mathrm{L} 2=$ Level 2: Technology concept and/or application formulated.

${ }^{d} \mathrm{~L} 3=$ Level 3: Analytical and experimental critical function and/or characteristic proof-of-concept.

eL 4=Level 4: Component and/or breadboard validation in laboratory environment.

${ }^{f} \mathrm{~L} 5=$ Level 5: Component and/or breadboard validation in relevant environment.

9L 6=Level 6: System/sub-system model or prototype demonstration in relevant environment.

${ }^{h} L$ 7=Level 7: System prototype demonstration in relevant environment.

'L 8=Level 8: Actual system completed and qualified through test and demonstration (not appliable)

j L 9=Level 9: Actual system proven through successful mission operations (not appliable)

Table 4: The Codes of Integration of Medical Services 


\begin{tabular}{|c|c|c|c|c|}
\hline No. & Authors and year & $\begin{array}{l}\text { The form of integrated medical } \\
\text { services }\end{array}$ & Sub-codes & Codes \\
\hline 1 & Armer et al., 2004 & $\begin{array}{l}\text { Telemedicine and } \\
\text { videoconferencing or without } \\
\text { videoconferencing }\end{array}$ & \multirow[t]{8}{*}{$\begin{array}{l}\text { Teleconsultation } \\
\text { and } \\
\text { videoconferencing }\end{array}$} & \multirow{18}{*}{$\begin{array}{l}\text { Integration of } \\
\text { medical } \\
\text { services in } \\
\text { telemedicine }\end{array}$} \\
\hline 2 & Daly et al., 2005 & $\begin{array}{l}\text { Teleconsulting, live video and } \\
\text { image transition }\end{array}$ & & \\
\hline 3 & $\begin{array}{l}\text { Chan et al., 2001; Hui \& Woo, 2002; Newbould et al., 2017; } \\
\text { Rabinowitz et al., 2010; Schneider et al., 2016; Toh et al., } \\
\text { 2015; Weiner et al., 2001; Weiner et al., } 2003\end{array}$ & $\begin{array}{l}\text { Videoconferencing and } \\
\text { teleconsultation }\end{array}$ & & \\
\hline 4 & Biglan et al., 2009; Grabowski \& O'Malley, 2014 & $\begin{array}{l}\text { Videoconferencing and } \\
\text { telemedicine }\end{array}$ & & \\
\hline 5 & Pallawala \& Lun, 2001 & $\begin{array}{l}\text { Videoconferencing, } \\
\text { teleconsultation and electronic } \\
\text { medical records }\end{array}$ & & \\
\hline 6 & Savenstedt et al., 2004 & $\begin{array}{l}\text { Videophones and } \\
\text { teleconsultation }\end{array}$ & & \\
\hline 7 & Cusack et al., 2008 & $\begin{array}{l}\text { Store-and-forward, real-time } \\
\text { video, hybrid systems and } \\
\text { teleconsultation }\end{array}$ & & \\
\hline 8 & Catic et al., 2014 & $\begin{array}{l}\text { Video-consultation technology } \\
\text { and teleconsultation }\end{array}$ & & \\
\hline 9 & Chang et al., 2010 & $\begin{array}{l}\text { Telemonitoring plus } \\
\text { teleconsultation via } \\
\text { videoconferencing }\end{array}$ & \multirow[t]{5}{*}{ Telemonitoring } & \\
\hline 10 & De Luca et al., 2016 & $\begin{array}{l}\text { Telemonitoring and } \\
\text { teleconsulting }\end{array}$ & & \\
\hline 11 & Pallikonda Rajasekaran et al., 2010 & $\begin{array}{l}\text { Shared health information } \\
\text { collected by wireless Sensor } \\
\text { Networks (WSNs) and } \\
\text { telemonitoring }\end{array}$ & & \\
\hline 12 & Zhang, 2017 & $\begin{array}{l}\text { Telemonitoring, wearable devices } \\
\text { and web-based health } \\
\text { information through an App }\end{array}$ & & \\
\hline 13 & $\begin{array}{l}\text { Delmastro et al., 2019; Deng, 2019; Wang, 2014; Mishkhal } \\
\text { et al. } 2020\end{array}$ & $\begin{array}{l}\text { Telemonitoring and wearable } \\
\text { devices }\end{array}$ & & \\
\hline 14 & Vowden \& Vowden, 2013; Zelickson, 2003 & $\begin{array}{l}\text { Teleconsultation without } \\
\text { videoconference (by digital } \\
\text { documents) }\end{array}$ & \multirow[t]{3}{*}{$\begin{array}{l}\text { Teleconsultation } \\
\text { and information } \\
\text { technologies }\end{array}$} & \\
\hline 15 & Janardhanan et al., 2008; Low et al. 2020 & $\begin{array}{l}\text { Internet (or email) and } \\
\text { teleconsultation }\end{array}$ & & \\
\hline 16 & Lavanya et al., 2006 & $\begin{array}{l}\text { Personal health information } \\
\text { management system (D-PHIMS) } \\
\text { and teleconsultation }\end{array}$ & & \\
\hline 17 & Doumbouya et al., 2015 & $\begin{array}{l}\text { Remote specialists and } \\
\text { teleconsultation for decision } \\
\text { making }\end{array}$ & \multirow{2}{*}{$\begin{array}{l}\text { Teleconsultation } \\
\text { and remote } \\
\text { specialist decision } \\
\text { making }\end{array}$} & \\
\hline 18 & Shafiee Hanjani et al., 2019 & $\begin{array}{l}\text { Telehealth and interprofessional } \\
\text { collaboration }\end{array}$ & & \\
\hline 19 & Liu \& Hsu, 2013 & $\begin{array}{l}\text { mhealth (App) and a soft motion- } \\
\text { sensing mattress }\end{array}$ & \multirow{4}{*}{$\begin{array}{l}\text { mHealth and } \\
\text { abnormal event } \\
\text { monitoring }\end{array}$} & \multirow{6}{*}{$\begin{array}{l}\text { Integration of } \\
\text { medical } \\
\text { services through } \\
\text { mHealth }\end{array}$} \\
\hline 20 & Mendes et al., 2017 & $\begin{array}{l}\text { Wearable devices and } \mathrm{m} \text {-health } \\
\text { personalised monitoring }\end{array}$ & & \\
\hline 21 & Delmastro et al., 2018 & $\begin{array}{l}\text { Mobile and e-health personalised } \\
\text { monitoring services }\end{array}$ & & \\
\hline 22 & Donnelly et al., 2018 & Mobile and wearable devices & & \\
\hline 23 & $\begin{array}{l}\text { Montalto et al., 2015; Dozet et al., 2016; Esteves et al., } \\
2019\end{array}$ & $\begin{array}{l}\text { Mobile and point-of-care } \\
\text { (radiography) }\end{array}$ & $\begin{array}{l}\text { mHealth and point- } \\
\text { of-care }\end{array}$ & \\
\hline 24 & Wälivaara et al., 2011 & Teleconsultation and mobile & mHealth and & \\
\hline
\end{tabular}

Page 31/36 
distance-spanning technology (MDST)

25 Crotty et al., 2014

Lai et al. 2020

27 Alexander, 2008; Alexander et al., 2015
Teleconsultation via

videoconferencing and web-

based health information

through an App

Smartphone-based

teleophthalmology platforms

Information management and clinical practice in different care departments

Clinical

information

integration

Electronic health record and technology-based devices

Table 5: The Codes of Stakeholders' Acceptability 


\begin{tabular}{|c|c|c|c|c|}
\hline Authors and year & Sub-codes & Description & Codes & Theme \\
\hline Huang et al., 2013 & Severity of illness & $\begin{array}{l}\text { The attributes of older adults include the severity of } \\
\text { illness and other individual sociodemographic variables. }\end{array}$ & $\begin{array}{l}\text { Attributes of } \\
\text { residents }\end{array}$ & $\begin{array}{l}\text { Attributes of residents } \\
\text { and } \mathrm{HCPs}^{\mathrm{a}}\end{array}$ \\
\hline Armer et al., 2004 & $\begin{array}{l}\text { Education } \\
\text { attainment }\end{array}$ & \multirow{3}{*}{$\begin{array}{l}\text { The identified attributes of HCPs include education } \\
\text { attainment, clinical working experience and the level of } \\
\text { tech-savvy. }\end{array}$} & \multirow[t]{3}{*}{$\begin{array}{l}\text { Attributes of } \\
\text { HCPs }\end{array}$} & \\
\hline $\begin{array}{l}\text { Handler et al., } \\
2013\end{array}$ & $\begin{array}{l}\text { Clinical working } \\
\text { experience }\end{array}$ & & & \\
\hline $\begin{array}{l}\text { Betgé-Brezetz et } \\
\text { al., 2009; Handler } \\
\text { et al., 2013; } \\
\text { Janardhanan et } \\
\text { al., } 2008\end{array}$ & $\begin{array}{l}\text { The level of tech- } \\
\text { savvy }\end{array}$ & & & \\
\hline $\begin{array}{l}\text { Abbate et al., } \\
2014 \text {; Chang et al., } \\
2009\end{array}$ & $\begin{array}{l}\text { Awareness from } \\
\text { external resources }\end{array}$ & $\begin{array}{l}\text { External information from HCPs, friends, } \\
\text { family members, and media sources. }\end{array}$ & $\begin{array}{l}\text { Persuasiveness } \\
\text { of external } \\
\text { information }\end{array}$ & \multirow[t]{11}{*}{$\begin{array}{l}\text { Coping process for } \\
\text { information and } \\
\text { technology appraisals }\end{array}$} \\
\hline $\begin{array}{l}\text { Eklund et al., } \\
2012 ; \text { Huang et al., } \\
2015\end{array}$ & $\begin{array}{l}\text { User } \\
\text { experience of } \\
\text { received benefit } \\
\text { from using a new } \\
\text { technology }\end{array}$ & \multirow[t]{2}{*}{$\begin{array}{l}\text { People acquire internal information by remembering } \\
\text { personal experiences from their earlier experiences and } \\
\text { satisfaction. }\end{array}$} & \multirow[t]{2}{*}{$\begin{array}{l}\text { Persuasiveness } \\
\text { of internal } \\
\text { information }\end{array}$} & \\
\hline $\begin{array}{l}\text { Chang et al., 2012; } \\
\text { Weiner et al., } \\
\text { 2003; Yu et al., } \\
\text { 2008; Zelickson, } \\
2003\end{array}$ & $\begin{array}{l}\text { Achievement of } \\
\text { user's satisfaction }\end{array}$ & & & \\
\hline $\begin{array}{l}\text { Betgé-Brezetz et } \\
\text { al., 2009; Bleda et } \\
\text { al., 2018; } \\
\text { Delmastro et al., } \\
\text { 2019; Qadri et al., } \\
\text { 2009; Savenstedt } \\
\text { et al., 2002; } \\
\text { Wälivaara et al., } \\
2011\end{array}$ & Usefulness & \multirow[t]{5}{*}{$\begin{array}{l}\text { The perceived efficaciousness of smart technologies } \\
\text { was linked to the perceived usefulness, performance } \\
\text { expectancy, relative advantage and pleasure experience } \\
\text { by the users which was instrumental in achieving } \\
\text { medical outcomes and meeting personal demands. }\end{array}$} & \multirow[t]{5}{*}{$\begin{array}{l}\text { Perceived } \\
\text { efficaciousness }\end{array}$} & \\
\hline $\begin{array}{l}\text { Alexander et al., } \\
\text { 2007; Alexander et } \\
\text { al., 2015; Handler } \\
\text { et al., 2013; } \\
\text { Janardhanan et } \\
\text { al., 2008; Qadri et } \\
\text { al., 2009 }\end{array}$ & $\begin{array}{l}\text { Helpfulness and } \\
\text { improvement in } \\
\text { care efficiency }\end{array}$ & & & \\
\hline $\begin{array}{l}\text { Chan et al., 2001; } \\
\text { Rabinowitz et al., } \\
\text { 2010; Weiner et } \\
\text { al., } 2003\end{array}$ & $\begin{array}{l}\text { A better solution } \\
\text { in administrative } \\
\text { procedures }\end{array}$ & & & \\
\hline $\begin{array}{l}\text { Crotty et al., 2014; } \\
\text { Handler et al., } \\
\text { 2013; Lavanya et } \\
\text { al., 2006; } \\
\text { Pallawala \& Lun, } \\
\text { 2001; Qadri et al., } \\
\text { 2009; Vowden \& } \\
\text { Vowden, 2013; } \\
\text { Okamoto et al. } \\
2021\end{array}$ & $\begin{array}{l}\text { Improvement in } \\
\text { quality of care }\end{array}$ & & & \\
\hline $\begin{array}{l}\text { Eklund et al., } \\
\text { 2012; Singh et al., } \\
2017\end{array}$ & $\begin{array}{l}\text { Assurance of } \\
\text { quality of life }\end{array}$ & & & \\
\hline Eklund et al., 2012 & $\begin{array}{l}\text { Improvement of } \\
\text { healthcare } \\
\text { accessibility } \\
\text { and availability }\end{array}$ & \multirow{3}{*}{$\begin{array}{l}\text { The perceived usability includes effort expectancy, } \\
\text { perceived ease of use, or perceived behavioral } \\
\text { control (22). The usability appraisals depend } \\
\text { on the availability or accessibility of these } \\
\text { options, necessary for care, easy to understand, learn } \\
\text { and use, affordability, compatible, the } \\
\text { availability of tech- } \\
\text { support during having difficulties of using a product, } \\
\text { and "human-centric" designs such as } \\
\text { matching preferences of users, portable and enjoyable to } \\
\text { use. }\end{array}$} & \multirow[t]{3}{*}{$\begin{array}{l}\text { Perceived } \\
\text { usability } \\
\text { (positive) }\end{array}$} & \\
\hline $\begin{array}{l}\text { Toh et al., 2015; } \\
\text { Tseng et al., } 2013\end{array}$ & Necessity for care & & & \\
\hline $\begin{array}{l}\text { Huang et al., 2015; } \\
\text { Janardhanan et } \\
\text { al., 2008; Lavanya } \\
\text { et al., 2006; Ohligs } \\
\text { et al. } 2020\end{array}$ & Easy to use & & & \\
\hline
\end{tabular}

Page 33/36 


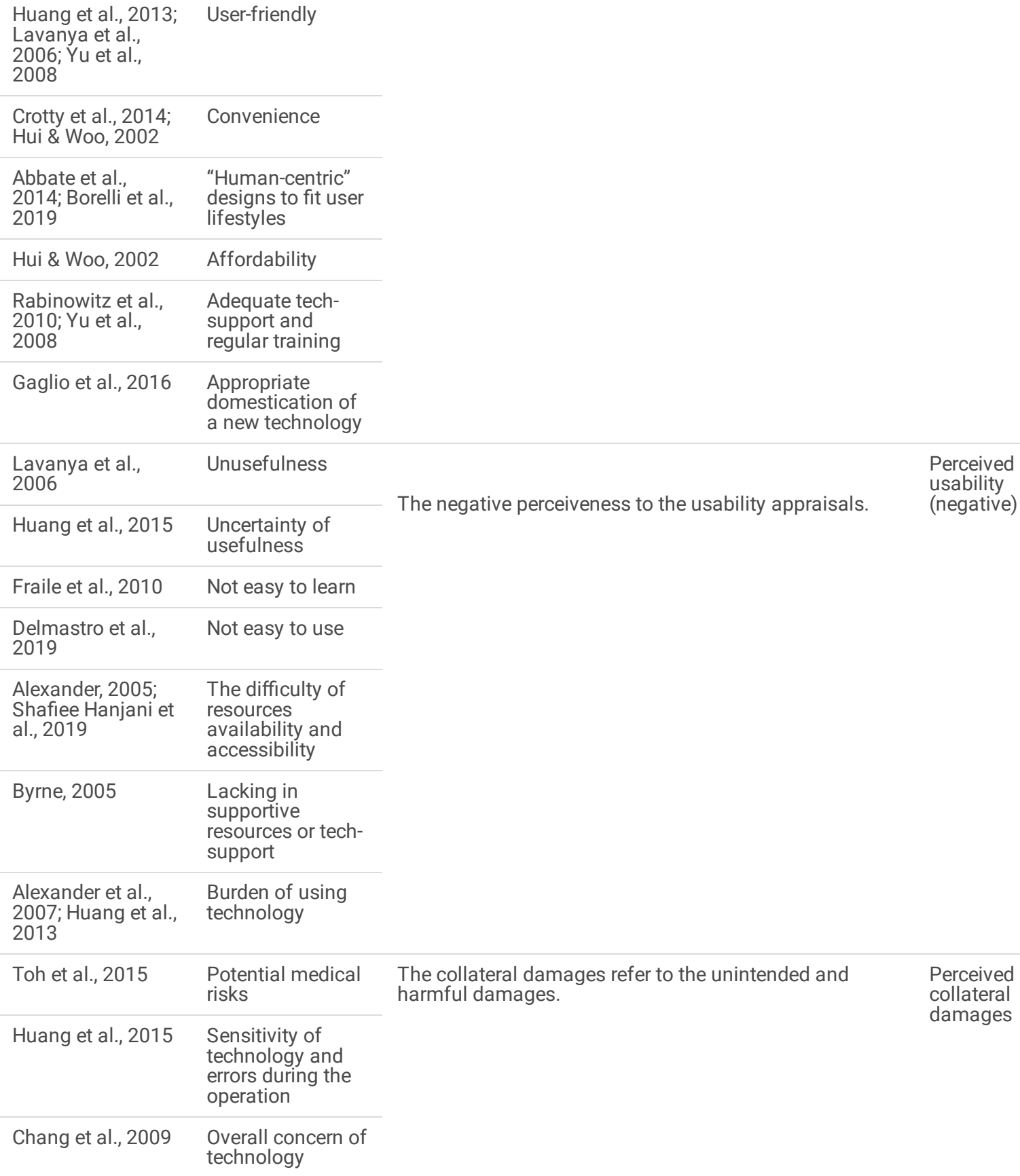

Chang et al., 2009 Overall concern of technology

${ }^{\mathrm{a}} \mathrm{HCPs}=$ Healthcare professionals

\section{Figures}




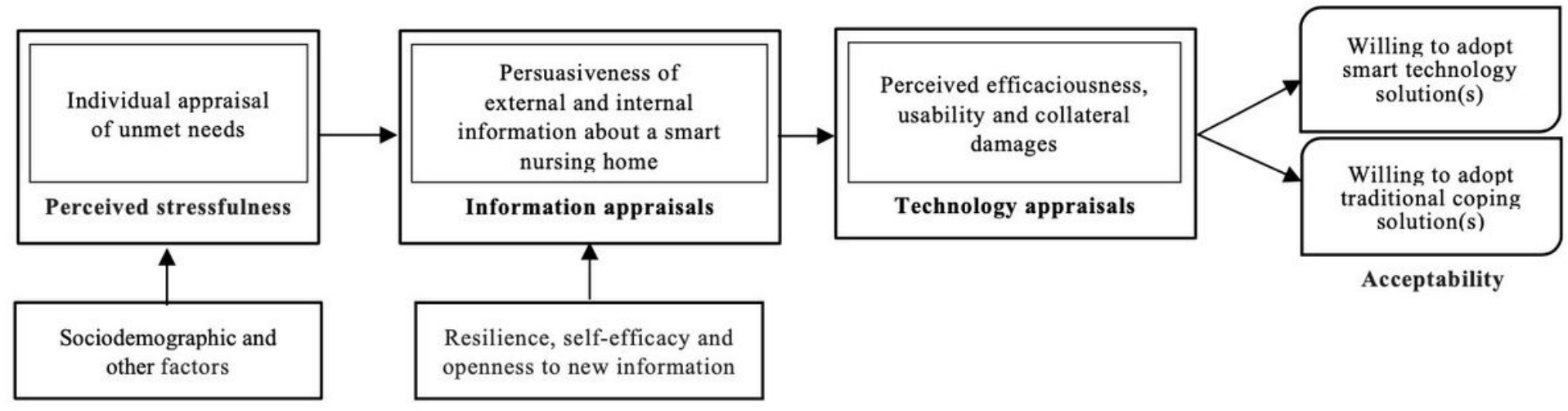

Figure 1

The Smart Technology Adoption Behaviors of Elderly Consumer Theoretical Model

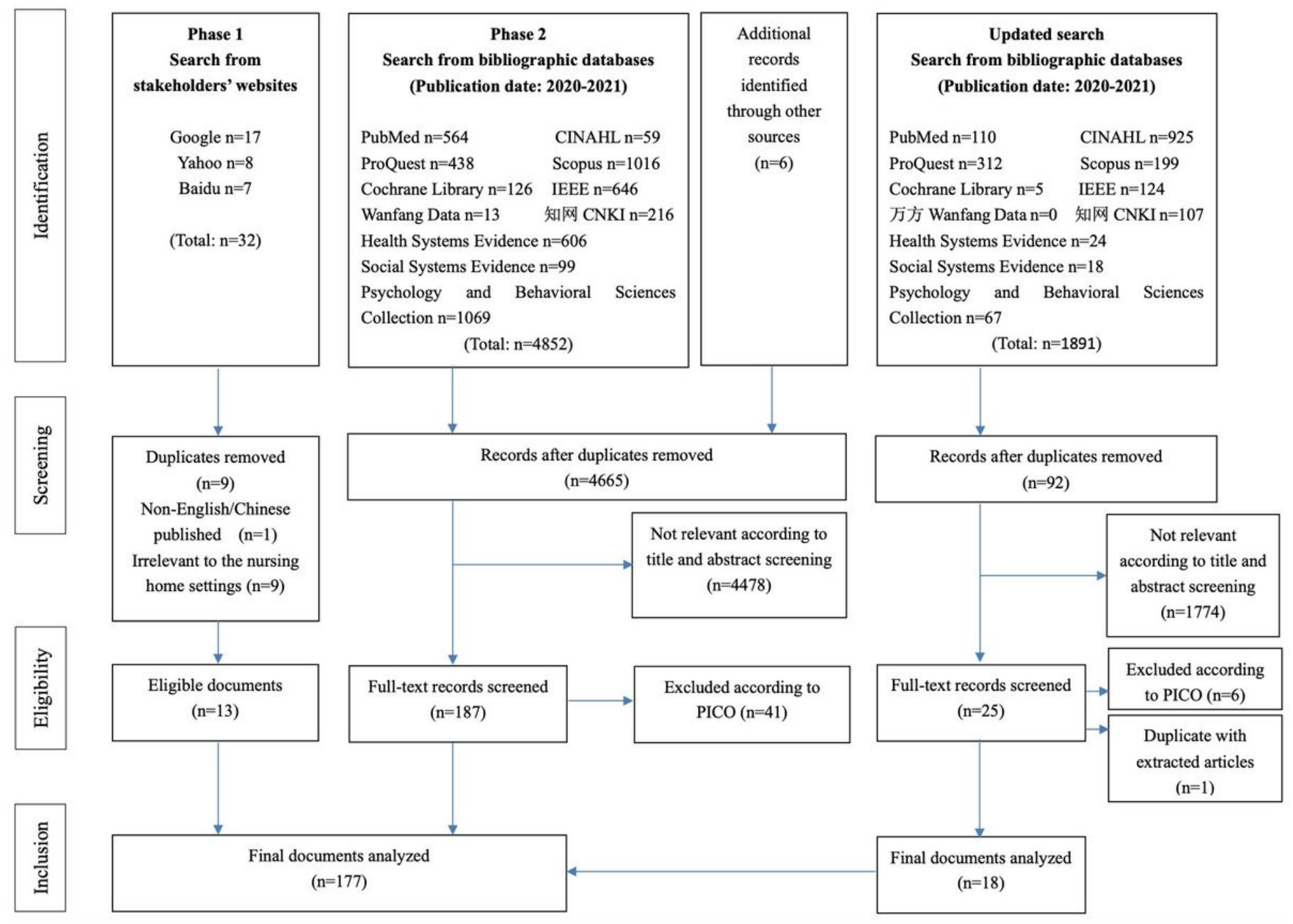

Figure 2

Scoping Review Flow Diagram 


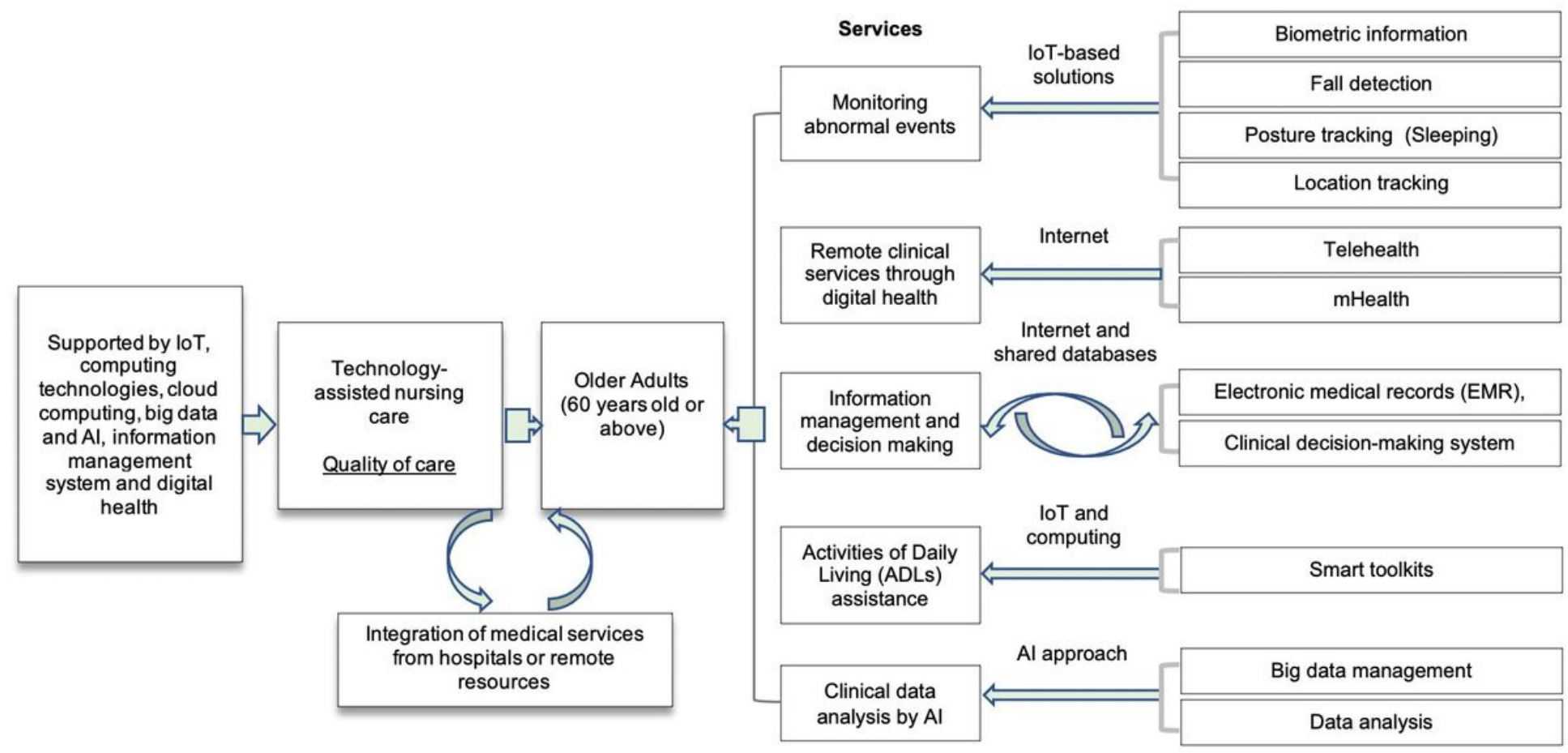

\section{Figure 3}

The Concept of a Smart Nursing Home

\section{Supplementary Files}

This is a list of supplementary files associated with this preprint. Click to download.

- AdditionalFile1SearchStrategyonDatabases.docx

- AdditionalFile2TheRetrievedLiterature.docx

- AdditionalFile3CodeSheetforDefining.docx

- AdditionalFile4IntegrationofMedicalServices.docx

- AdditionalFile5stakeholdersacceptability.docx

- AdditionalFile1PRISMAchecklistreview.docx 